\title{
37. CLIMATIC CYCLICITY AT SITE 806: THE GRAPE RECORD ${ }^{1}$
}

\author{
Larry A. Mayer, ${ }^{2}$ Eystein Jansen, ${ }^{3}$ Jan Backman, ${ }^{4}$ and Toshiaki Takayama ${ }^{5}$
}

\begin{abstract}
We used the continuous saturated bulk density records collected by the gamma-ray attenuation porosity evaluator (GRAPE) at Ocean Drilling Program Site 806 on the top of the Ontong Java Plateau to evaluate the continuity of the recovered cores and to splice together a complete section from the multiple holes drilled at the site (for the upper $165 \mathrm{~m}$, this is equivalent to approximately 0-5 Ma). The lack of offset in core breaks (between the 9.5-m-long, successive cores) from hole to hole made splicing difficult, and the results are not unambiguous. The composite section was converted to a time series by using biostratigraphy and supplementing this with oxygen-isotope datums for the interval between 2 and $5 \mathrm{Ma}$. Evolutionary spectra generated from the composite section clearly indicate the presence of Milankovitch frequencies throughout the record. We chose a final age model that was most consistent with a Milankovitch model but have not, as yet, spectrally tuned the data.

The GRAPE (saturated bulk density) changes at Site 806 are the result of changes in grain size, with density decreasing as grain size increases. We attribute this to the removal of fine particles by winnowing, leaving a greater percentage of large hollow foraminifers behind - "the winnowing effect." This is in contrast to the "dissolution effect," which breaks up large hollow foraminifers into fragments but merely transfers intraparticle porosity to interparticle porosity and thus shows significant changes in grain size without significant changes in density. A 300-k.y. piston core record reveals that during this time interval increased winnowing has been associated with glacials and 100-k.y. cyclicity. For the time interval from 5 to $2 \mathrm{Ma}$, enhanced winnowing continues to be associated with isotopically heavy intervals dominated by $41-k . y$. (obliquity) variance. In this band, the winnowing record is highly correlated with the ice-volume record, particularly since the onset of Northern Hemisphere glaciations. Before that time, the grain-size record continues to show variance in the obliquity band whereas the oxygen isotope record shows a shift to the dominance of precessional frequencies. We suggest that the winnowing signal is a response to increased thermohaline circulation and benthic storm activity associated with enhanced north-south thermal gradients during times of climatic degradation.
\end{abstract}

\section{INTRODUCTION AND BACKGROUND}

The Ontong Java Plateau is a massive volcanic edifice in the western equatorial Pacific that has collected an almost 1-km thick sequence of nearly pure pelagic carbonates over the past 100 m.y. This thick, relatively well-preserved accumulation of pelagic carbonate contains a detailed record of the history of the ocean and climate (much of the plateau has remained above the calcite compensation depth for most of its history). Because of the unique topographic and geographic characteristics of the plateau, it has been the focus of numerous paleoceanographic studies, the most recent of which is Ocean Drilling Program (ODP) Leg 130 (Berger et al., in press). The goal of these studies has been to reconstruct, through the use of a number of paleoceanographic proxies, a detailed history of the changes in ocean circulation, ocean chemistry, and climate in the region and to use these reconstructions to draw inferences about global conditions.

To construct a detailed time series of the primary paleoclimatic proxies (e.g., abundances and isotopic composition of microfossil tests, carbonate content, and grain size), closely spaced, discrete samples as well as expensive and time-consuming preparation and analyses are required. The constraints of time and money and the physical limits of sample size have resulted in a trade-off between sample density (paleoclimatic resolution) and the time interval over which the study is conducted (i.e., extremely high-resolution studies have been limited to relatively short intervals of high sedimentation

\footnotetext{
${ }^{1}$ Berger, W.H., Kroenke, L.W., Mayer, L.A., et al., 1993. Proc. ODP, Sci. Results, 130: College Station, TX (Ocean Drilling Program).

${ }^{2}$ Ocean Mapping Group, Department of Surveying Engineering, University of New Brunswick, P.O. Box 4400, Fredericton, New Brunswick E3B 5A3, Canada.

${ }^{3}$ Section B, Department of Geology, University of Bergen, Allegaten 41, N-5007 Bergen, Norway.

${ }_{4}^{4}$ Department of Geology, University of Stockholm, S-106 91 Stockholm, Sweden.

${ }^{5}$ Department of Geology, College of Liberal Arts, Kanazawa University, 1-1 Marunouchi, Kanazawa 920, Japan.
}

rate). Recently, however, we have seen that the near-continuous, gamma-ray attenuation data (GRAPE) collected from cores on board the JOIDES Resolution can be used to produce extremely high-resolution paleoclimatic time series very rapidly and over long sections of the geologic record (Mayer, 1991). In this paper we take a detailed look at the GRAPE record of Site $806\left(0^{\circ} 19.11^{\prime} \mathrm{N}, 159^{\circ} 21.69^{\prime} \mathrm{E}\right.$, 2520-m water depth) on the Ontong Java Plateau and explore its potential as a paleoceanographic tool.

The gamma-ray attenuation porosity evaluator (GRAPE) was originally developed by scientists at the Marathon Oil Company (Evans, 1965 ) and has been used on board the JOIDES Resolution during the Ocean Drilling Program and on its predecessor, the GLOMAR Challenger, since the earliest legs of the Deep Sea Drilling Project (DSDP) (Evans and Cotterell, 1970). Basically, the system consists of a computer-controlled, motor-driven track that moves a whole core between a focused gamma-ray source $\left({ }^{137} \mathrm{Cs}\right)$ and a scintillation counter. As the core moves between the source and the scintillation counter, a nearcontinuous measure of the attenuation of gamma rays is recorded as a function of depth in the core. The spacing of these measurements is a function of the speed of the track and the length of the count; typically readings are taken every 0.5 to $2 \mathrm{~cm}$. The attenuation of gamma rays through the core can be directly related to the saturated bulk density of the sediment (wet weight per unit volume) if a constant mineralogical attenuation coefficient is assumed (quartz is used for the ODP system). For details of the theory of gamma-ray attenuation, the reader is referred to Evans (1965), Harms and Choquette (1965), Preiss (1968), and Brier et al. (1969); for details of the DSDP/ODP system, see Boyce (1973). The GRAPE system presently installed on the JOIDES Resolution is incorporated into a multisensor track (Schultheiss and McPhail, 1989) that also collects near-continuous magnetic susceptibility and compressional wave velocity data.

Despite the fact that the GRAPE can produce nearly continuous profiles of saturated bulk density, data from the DSDP/ODP system have rarely been used in paleoceanographic studies. In part, this may have been as a result of the intimidating volume of data produced by the system, but most probably it is because the GRAPE system was 


\section{Carbonate (\%)}

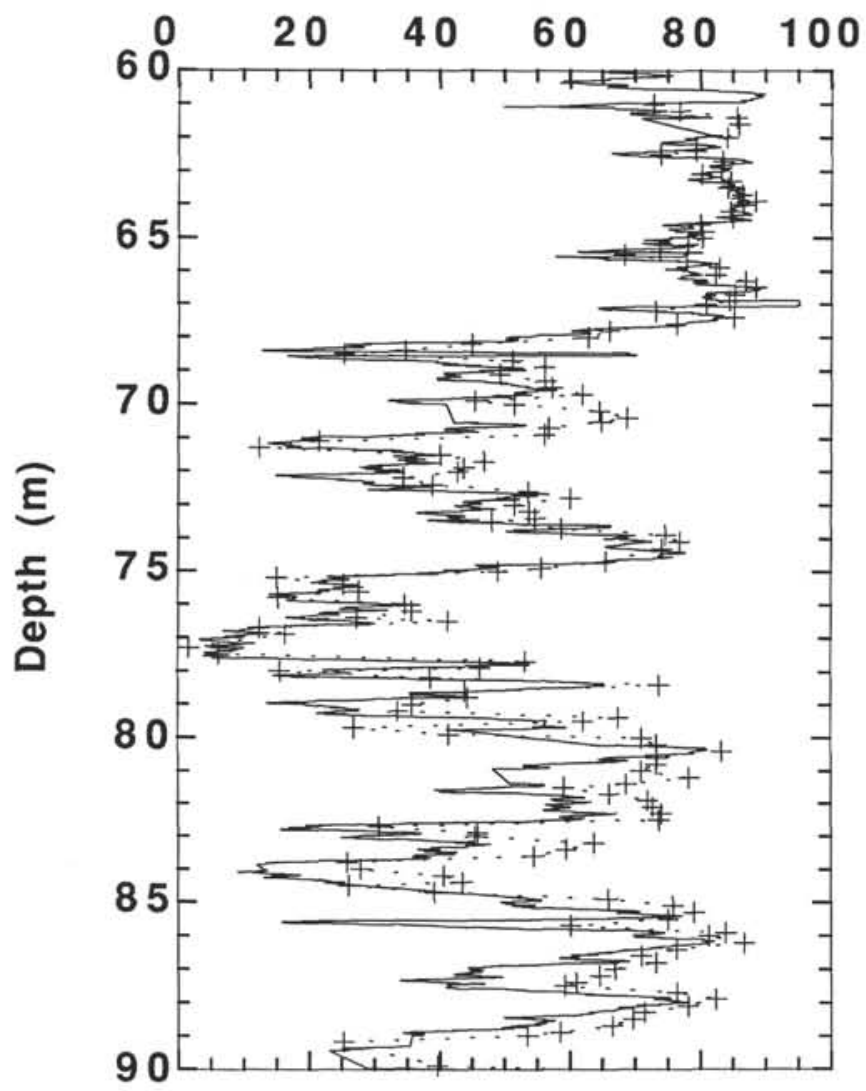

Figure 1. Example of prediction of carbonate content from GRAPE data, Site 574. Solid line is the predicted carbonate data, and dashed line connects discrete samples measured with carbonate bomb. GRAPE prediction has ten times the resolution of discrete samples. See Mayer (1991) for details.

in the domain of the "physical properties specialists" and not viewed as a paleoceanographic tool. In an examination of GRAPE data from DSDP Leg 85 in the central equatorial Pacific, however, Mayer (1991) demonstrated that in this environment, the GRAPE data can be accurately transformed to percentage calcium carbonate and thus used to generate long (4-5 m.y.), ultra-high-resolution (500$1000 \mathrm{yr}$ sample interval) time series of carbonate content, an important paleoceanographic parameter (Fig. 1). It was also shown that these long, high-resolution time series could be used to examine the time-varying response of the ocean system to orbital (Milankovitch) forcing over a time interval and at a resolution not achievable before (Fig. 2). The applicability of the GRAPE/carbonate relationship has been refined and extended to the equatorial and north Atlantic and the continuous, detailed records produced have, in turn been used to "tune" the stratigraphy (Herbert, in press; Herbert and Mayer, in press).

GRAPE data can also play another extremely important role in paleoceanographic studies by providing a means to evaluate the continuity of the recovered section. A primary goal of any paleoceanographic drilling program is to recover the most complete and undisturbed section possible. Unfortunately, it has been shown that, even with the advanced hydraulic piston corer (APC), inevitable gaps occur between the successive 9.5-m cores (Heath et al., 1985; Ruddiman et al., 1987). To insure $100 \%$ recovery, each site is typically drilled two or more times, with the core breaks offset. The near-continuous nature and large-amplitude fluctuations characteristic of the GRAPE records in the central Atlantic and Pacific make these records an ideal tool for evaluating core gaps and for constructing more complete "composite" sections.

In this paper we will (1) examine the use of the GRAPE record for evaluating the completeness of core recovery and for constructing a "composite" section and optimum time scale; (2) look at the source of the saturated bulk-density variations that create the GRAPE signal in Ontong Java Plateau sediments; and (3) explore the paleoceanographic significance of the cyclicity in the Site 806 GRAPE record.

\section{METHODS AND APPROACH}

\section{Initial Data Capture and Processing}

On Leg 130, the multisensor track speed was such that multiple (2-10 depending on the other sensors activated at the time) attenuation (directly converted to saturated bulk density) readings were made at approximately a $1-\mathrm{cm}$ sample interval. These data were logged onto a personal computer, section by section, and transferred to the shipboard VAX computer at the completion of each hole. Processing on the VAX included the concatenation of each section into a complete profile as a function of depth in hole, the removal of obvious outliers (out of the range of $1.2-3.0 \mathrm{~g} / \mathrm{cm}^{3}$ ), the averaging of all readings at the same depth, and finally the application of a 10-point moving average to apply some smoothing to the data. In the course of this processing, the uppermost section of each $9.5-\mathrm{m}$ core was flagged as experience has shown us that these upper sections are particularly susceptible to core disturbance. Smoothed data were then transferred back to Macintosh format for further display and manipulation. Thus, the primary working data file is a 1-cm sample interval, 10 -point smoothed data set of saturated bulk density vs. depth values, with the uppermost part of each 9.5-m section flagged.

\section{Construction of Composite Section}

In an attempt to assure complete core recovery, three parallel APC holes were drilled at Site 806 (Holes 806A, 806B, and 806C). Unfortunately, as will be shown below, the core breaks were not well offset, and it is difficult to guarantee complete recovery of the section. In part, this was a result of the inability to monitor, in real time, the output of the continuous core scanners of the multisensor track. For a subsequent ODP paleoceanographic cruise (Leg 138), specialized software and work stations were developed to monitor, in near real time, the output of the laboratory core scanners. Using this approach, Leg 138 scientists were able to guide the drillers actively and to assure complete recovery of the section. The reader is referred to Hagelberg et al. (in press) for a complete discussion of the approach used on Leg 138.

The construction of a composite section begins with the identification of a number of "events" on the GRAPE record. Figure 3 shows an example of this process from the interval between 20 and $30 \mathrm{~m}$ below seafloor (mbsf) in Holes 806A, 806B, and 806C. Events are matched from hole to hole based on visual correlation; in making these correlations, we try to match both the shape and the absolute amplitude of the curves. Experience has shown us that material is often missing (from centimeters to meters; see Hagelberg et al., in press) in the gap between cores, and that the sediment recovered in the upper part of each 9.5-m core (Section 1) is often disturbed. This disturbance is particularly evident in the plot of Hole 806B in Figure 3. Core disturbance typically results in decreased saturated bulk density, and thus we tend to be more suspicious of low-density values than we are of high-density values. In matching parallel holes, we maintain the integrity of the 9.5 - $\mathrm{m}$ core length but allow the position of the core breaks to float. We shift one core against the next and try to maximize fit. At this stage we do not stretch or shrink the curve within a $9.5-\mathrm{m}$ core length, though clearly differential stretching and compaction of core material occurs. Figure 3B shows Holes 806A, $806 \mathrm{~B}$, and $806 \mathrm{C}$ shifted for maximum fit. Although some peak matches are unambiguous, others are clearly problematical. The 


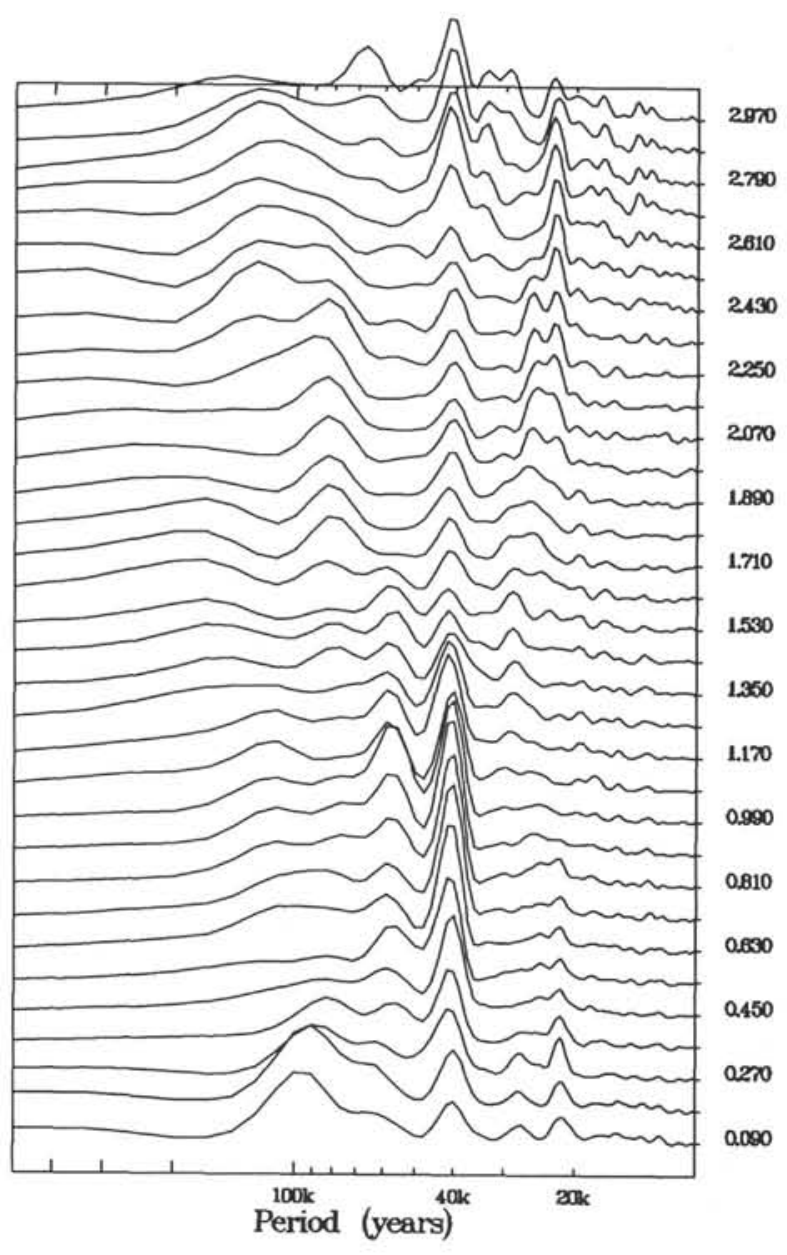

Figure 2. Example of evolutionary spectra based on GRAPE data (converted to percent carbonate) from DSDP Site 573. The first spectrum (bottom of figure) represents the time interval from 90,000 to $900,000 \mathrm{Ma}$. Each successive spectrum represents an offset of $90,000 \mathrm{yr}(90 \%)$ and a $900,000-\mathrm{yr}$ window. The age axis is keyed to the beginning of each window. The spectra are variance conserving.

problems are most serious in the region of the core breaks (see Fig. $3 \mathrm{~A}$ ), but unfortunately at Site 806 almost all of the core breaks in Holes $806 \mathrm{~A}, 806 \mathrm{~B}$, and $806 \mathrm{C}$ overlapped (rather than the ideal, which is a 3-4 m offset). Thus, the multiple holes cannot resolve this ambiguity and guarantee continuous core recovery. Accepting this correlation between holes, we see that about $1 \mathrm{~m}$ of material is missing between Cores $130-806 \mathrm{~B}-3 \mathrm{H}$ and $-4 \mathrm{H}, 2 \mathrm{~m}$ of material is missing between Cores $130-806 \mathrm{C}-3 \mathrm{H}$ and $-4 \mathrm{H}$, and about $0.7 \mathrm{~m}$ is missing between Cores $130-806 \mathrm{~A}-3 \mathrm{H}$ and $-4 \mathrm{H}$.

In the upper $150 \mathrm{~m}$ of Site 806, approximately 70 events were identified and, through the process described above, a composite section was constructed. In constructing the composite, the philosophy was to avoid core breaks (in the few intervals where the cores were properly offset) and to maintain a continuity of amplitude as well as wave form. Where possible, we used Hole 806B because most detailed isotopic studies were conducted on this hole. The depths of the major events identified in their respective holes is presented in Table 1; the construction of the composite section is described in Table 2. It is important to note that when the composite is constructed, a new depth scale is generated. Following the lead of the Leg 138 scientists (Hagelberg et al., 1992), we will refer to this depth scale as meters composite depth (mcd). Figure 4 illustrates the depth of events in Hole $806 \mathrm{~B}$ vs. their depth in the composite section.
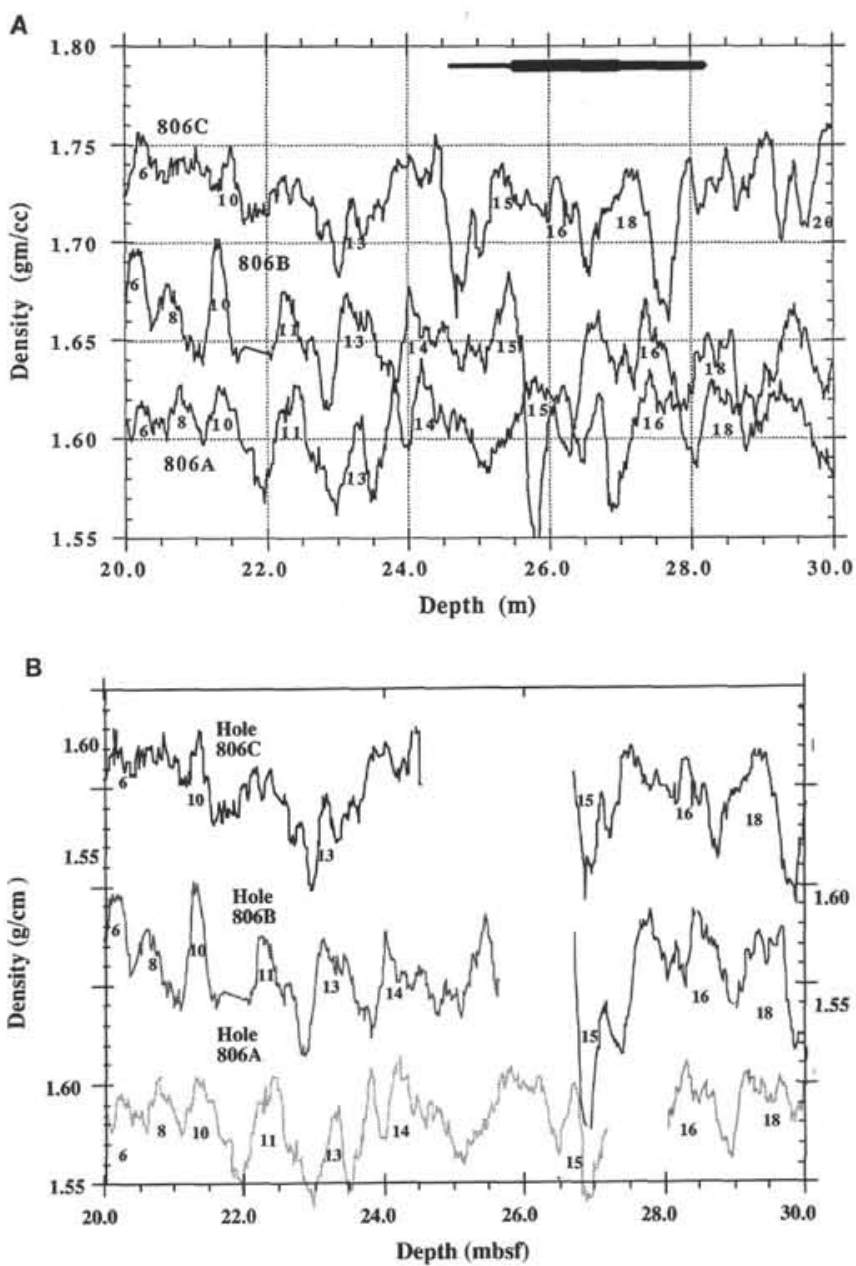

Figure 3. A. Plot of GRAPE density vs. shipboard depth for 10-m intervals in Holes $806 \mathrm{~A}, 806 \mathrm{~B}$, and $806 \mathrm{C}$. Matched events are marked by numbers. Flag bars indicate the position of uppermost section of each core (position of break between two successive APC cores). B. Construction of composite section through splicing, Site 806 . Curves have been broken at core breaks and allowed to shift so as to achieve best fit (by eye) of events. Once correlations are made, the section was spliced together to achieve continuous record.

\section{Conversion to Time Series}

If we are to explore the paleoceanographic significance of the Site 806 GRAPE data, we must place the data in a stratigraphic framework. Our approach to placing the data within a time frame has been to begin with the best stratigraphy possible on the individual holes and then map these stratigraphic picks onto the spliced depth scale. Unfortunately, the severe reduction of magnetite, producing dissolved and reduced iron at Site 806 results in no measurable magnetostratigraphy below about 10 mbsf (Kroenke, Berger, Janecek, et al., 1991). Therefore, we are limited to biostratigraphic picks for our initial estimates of age. Our initial time scale was based on the few nannofossil datums determined in detail in Hole 806B (Table 3). The age picks for the nannofossil datums were taken from Backman and Shackleton (1983) with calibration to the time scale of Berggren et al. (1985). The age of the last occurrence (LO) of Discoaster pentaradiatus (2.39 Ma) is from Raymo et al. (1989).

These biostratigraphic picks were mapped onto the new spliced depth scale (mcd) for Site 806, thereby constructing a new age/depth table (Table 3). Based on this initial time scale, we converted the data from the depth domain (mcd) into the time domain by linear interpolation between age control points and calculated the spectral compo- 
Table 1. List of events used to correlate Holes 806A, 806B, and 806C.

\begin{tabular}{|c|c|c|c|c|}
\hline Event & $\begin{array}{c}\text { Hole } \\
806 \mathrm{~A} \\
\text { (mbsf) }\end{array}$ & $\begin{array}{c}\text { Hole } \\
806 \mathrm{~B} \\
\text { (mbsf) }\end{array}$ & $\begin{array}{c}\text { Hole } \\
806 \mathrm{C} \\
\text { (mbsf) }\end{array}$ & $\begin{array}{l}\text { Splice } \\
\text { (mcd) }\end{array}$ \\
\hline 0.5 & 3.54 & 4.06 & 3.85 & 3.84 \\
\hline 1 & 11.30 & 11.92 & 11.61 & 11.61 \\
\hline 5 & 13.22 & 13.91 & 13.57 & 13.53 \\
\hline $\mathrm{R}$ & 17.40 & 16.80 & & 17.71 \\
\hline 6 & 20.21 & 20.17 & 20.25 & 21.09 \\
\hline 1.0 & 21.33 & 21.32 & 21.50 & 22.24 \\
\hline 1.1 & 22.28 & 22,28 & & 23.20 \\
\hline 1.3 & 23.32 & 23.13 & 23.19 & 24.05 \\
\hline 1.5 & 26.25 & 25.40 & 25.25 & 26.33 \\
\hline 1.6 & 27.43 & 27.36 & 26.11 & 27.14 \\
\hline 1.8 & 28.78 & 28.58 & 27.26 & 28.29 \\
\hline 20 & 31.19 & 31.34 & 29.95 & 30.98 \\
\hline 2.1 & 32.12 & 32.12 & 30.95 & 31.98 \\
\hline 26 & 34.95 & 34.83 & 33.71 & 34.74 \\
\hline 27 & 36.31 & 35.54 & 35.44 & 36.47 \\
\hline 28 & 36.74 & 36.13 & 36.07 & 37.10 \\
\hline 30 & 37.54 & 36.97 & 36.80 & 37.83 \\
\hline 32 & 38.33 & 37.90 & 37.58 & 38.61 \\
\hline 34.2 & 41.89 & 40.93 & 40.71 & 41.74 \\
\hline $\mathrm{T}$ & 43.25 & 42.10 & 42.20 & 43.23 \\
\hline 36 & 48.09 & 46.70 & 47.13 & 47.84 \\
\hline 39 & 48.99 & 47.57 & 47.85 & 48.71 \\
\hline 4.1 & 49.55 & 48.09 & 48.47 & 49.23 \\
\hline 41.5 & 50.50 & 49.00 & 49.58 & 50.14 \\
\hline 41.6 & 50.90 & 49.50 & & 50.67 \\
\hline 41.8 & 51.56 & 51.30 & 50.25 & 51.33 \\
\hline 44 & 53.60 & 53.11 & 52.27 & 53.37 \\
\hline 45 & 54.55 & & 54.36 & 54.32 \\
\hline 46 & 54.87 & 54.56 & 54.66 & 54.61 \\
\hline 48 & 55.61 & 55.52 & 55.37 & 55.59 \\
\hline 50 & 56.67 & 56.44 & 56.49 & 56.51 \\
\hline 52 & 57.70 & 58.56 & 57.73 & 58.63 \\
\hline 53 & 58.28 & 59.20 & 58.30 & 59.27 \\
\hline 57 & 61.28 & 62.21 & 60.87 & 62.28 \\
\hline 58 & 61.99 & 62.83 & 61.52 & 62.90 \\
\hline 59 & 62.64 & 63.35 & 62.20 & 63.42 \\
\hline 60 & 65.71 & 66.45 & 65.71 & 66.52 \\
\hline 6.1 & 66.55 & 67.07 & 66.64 & 67.14 \\
\hline 62 & 66.95 & 67.73 & 67.04 & 67.80 \\
\hline 64 & 67.54 & 68.19 & 67.54 & 68.26 \\
\hline 6.6 & 67.97 & 68.66 & 68.04 & 68.73 \\
\hline 68 & 69.52 & 70.06 & 69.52 & 70.13 \\
\hline 70 & 69.80 & 70.50 & 70.10 & 70.57 \\
\hline 71 & 71.03 & 71.50 & & 71.57 \\
\hline 73 & 71.31 & 71.74 & & 71.81 \\
\hline 75 & 72.23 & 72.64 & & 72.71 \\
\hline 76 & 73.42 & 74.01 & 73.57 & 73.91 \\
\hline 77 & 73.60 & 74.22 & 73.82 & 74.09 \\
\hline 78 & 73.85 & 74.59 & 74.31 & 74.34 \\
\hline 80 & 74.75 & 75.34 & 75.12 & 75.1 \\
\hline 81 & 75.09 & 76.45 & 75.31 & 76.21 \\
\hline 82 & 76.55 & 77.48 & 77.42 & 77.24 \\
\hline 84 & 76.98 & 77.91 & & \\
\hline 85 & & 80.00 & 80.58 & 80.42 \\
\hline 87 & & 80.59 & 81.14 & 81.01 \\
\hline 89 & & 82.11 & 82.63 & 82.53 \\
\hline 90 & & 83.35 & 83.66 & 83.77 \\
\hline 92 & & 83.69 & 84.12 & 84.11 \\
\hline 94 & & 84.18 & 84.52 & 84.6 \\
\hline 95 & & 85.00 & 85.46 & 85.42 \\
\hline 97 & & 85.34 & 85.90 & 85.76 \\
\hline 99 & & 86.55 & 87.32 & 86.97 \\
\hline 101 & & 87.20 & 87.82 & 87.62 \\
\hline 104 & & 95.56 & 94.56 & 95.98 \\
\hline 105 & & 96.80 & 95.77 & 97.22 \\
\hline 106 & & 98.47 & 97.54 & 98.89 \\
\hline 107 & & 98.66 & 97.76 & 99.08 \\
\hline 108 & & 99.12 & 98.38 & 99.54 \\
\hline 109 & & 99.43 & 98.63 & 99.85 \\
\hline 112 & & 102.29 & 102.61 & 102.71 \\
\hline
\end{tabular}

Notes: Events (in first column) are given either in numbers or letters. The depth of these events (in mbsf) are listed in the next three columns. The final position of the event in the spliced section (in mcd) is given in the last column. nents of the time series using the standard analytical procedures adopted by the SPECMAP project (Jenkins and Watts, 1968; Imbrie et al., 1984). Unlike many previous studies, however, the continuous, high-resolution nature of the time series permits us to view the data in the form of an "evolutionary spectrum" (e.g., Fig. 2) that can be used to evaluate the relative merits of the stratigraphy as well as provide insight into the response, through time, of the ocean to external forcing.

Earlier studies have shown that GRAPE records in the central equatorial Pacific are accurate representations of downcore changes in carbonate content, which are, in turn, a reflection of orbitally driven (in part) changes in ocean chemistry (Mayer, 1991). This relationship has been elegantly demonstrated in the eastern equatorial Pacific where GRAPE records have been shown to be correlative over large distances and capable of providing a stratigraphic framework (Shackleton et al., 1992). Based on these experiences and a preliminary shipboard study of the Leg 130 GRAPE records (Jansen et al., 1991), we view the evolutionary spectra with the assumption that we should see Milankovitch frequencies in the record and that small deviations from Milankovitch periods probably represent inadequacies in the time scale.

Figure 5 shows the evolutionary spectrum using just the biostratigraphic datums. For this and all of the evolutionary spectra displayed here, each spectrum represents a 900,000-yr window beginning at the time equivalent to the intersection of the spectrum and the $y$-axis $(0$ in Fig. 5). Each successive spectrum represents an offset of $90,000 \mathrm{yr}$ ( $90 \%$ overlap) and a 900,000-yr window. The presence of significant energy in the Milankovitch bands is clearly evident in this figure; it is also clear that the time scale needs some improvement, particularly in the 1.8 to $3 \mathrm{Ma}$ interval.

To improve the stratigraphy in this interval, we add supplemental information provided by the oxygen isotope record measured at Hole $806 \mathrm{~B}$ (Jansen et al., this volume). Based on the detailed oxygen isotope records of Sites 607 and 677, Raymo et al. (1989, 1990) produced a complete isotope stratigraphy and defined isotope stages through the entire Quaternary and major portions of the late Pliocene. They defined Stage 100, which is a very pronounced glacial episode with a large positive $\delta^{18} \mathrm{O}$ excursion, just above the Gauss/Matuyama magnetic reversal, conventionally dated to $2.47 \mathrm{Ma}$. Similarly, a very strong glacial is recorded in Hole $806 \mathrm{~B}$ at $55.33 \mathrm{mbsf}$. As is also true for Stage 100 in the record of Raymo et al. (1989), the Hole 806B event is located immediately beneath the LO of $D$. pentaradiatus, which is at $54.68 \mathrm{mbsf}$ in Hole 806B. This close correspondence with Stage 100 (as defined in Sites 607 and 677) and the LO of the D. pentaradiatus datum makes us conclude that the strong glacial at $55.33 \mathrm{mbsf}$ in Hole 806B is Stage 100. We then examined the oxygen isotope record further downcore and were able to identify Stages 104 and 116 (the first main glacial isotope enrichment in the late Pliocene; Raymo et al., 1989). The isotope stage determinations are documented in Figure 6.

Shackleton et al. (1990) recently proposed a revision of the magnetic time scale based on tuning the isotope record from ODP Site 677 to both 41- and 23-k.y. periodicities. This approach led the authors to conclude that the radiometrically determined ages for the Pleistocene magnetic reversals may be $5 \%-7 \%$ too low and to postulate that this may be caused by inaccuracies in the radiometric dating of the magnetic reversals. To see the effects of this time scale on our records, we recalculated the time scale by using the new ages proposed by Shackleton et al. (1990) and by adding 5\% to the ages used for the previous time scale for events older than $2.6 \mathrm{Ma}$ (the age limit in the study of Shackleton et al., 1990). The results of this procedure are presented in Figure 7. As can be seen in this figure, the spectral behavior of the time series, particularly in the interval from 3.0 to $1.5 \mathrm{Ma}$, is improved using this time scale. A comparison of the age-depth relationships derived from the shipboard biostratigraphy and that derived from the Shackleton et al. (1990) time scale is presented in Figure 8.

Though improved over the shipboard biostratigraphy, the agedepth relationship revealed in the evolutionary spectra of the Site 
Table 2. Makeup of composite section.

\begin{tabular}{cccccc}
\hline Event & $\begin{array}{c}\text { Original } \\
\text { depth (mbsf) }\end{array}$ & $\begin{array}{c}\text { Original } \\
\text { thickness (mbsf) }\end{array}$ & $\begin{array}{c}\text { Original } \\
\text { hole }\end{array}$ & $\begin{array}{c}\text { Spliced } \\
\text { depth (mcd) }\end{array}$ & $\begin{array}{c}\text { Change to } \\
\text { original depth (m) }\end{array}$ \\
\hline $0-0.5$ & $0-3.84$ & 3.8 & $806 \mathrm{C}$ & $0-3.84$ & 0 \\
$0.5-\mathrm{R}$ & $3.54-17.40$ & 14.0 & $806 \mathrm{~A}$ & $3.86-17.71$ & 0.3 \\
R-15 & $16.80-25.41$ & 8.6 & $806 \mathrm{~B}$ & $17.72-26.32$ & 0.9 \\
$15-\mathrm{T}$ & $25.31-42.20$ & 17.0 & $806 \mathrm{C}$ & $26.33-43.23$ & 1.0 \\
T-41.6 & $42.10-49.50$ & 7.4 & $806 \mathrm{~B}$ & $43.24-50.64$ & 1.1 \\
$41.6-46$ & $50.90-54.86$ & 4.0 & $806 \mathrm{~A}$ & $50.67-54.61$ & -0.2 \\
$46-75$ & $54.56-72.65$ & 18.0 & $806 \mathrm{~B}$ & $54.63-72.72$ & 0.1 \\
$75-78$ & $72.23-73.85$ & 1.6 & $806 \mathrm{~A}$ & $72.73-74.34$ & 0.5 \\
$78-82$ & $74.59-77.49$ & 2.9 & $806 \mathrm{~B}$ & $74.35-77.24$ & -0.2 \\
$82-85$ & $77.41-80.59$ & 3.2 & $806 \mathrm{C}$ & $77.26-80.42$ & -0.2 \\
$85-$ end & $80.00-164.00$ & 84.0 & $806 \mathrm{~B}$ & $80.43-164.42$ & 0.4 \\
\hline
\end{tabular}

Notes: The events column specifies the interval used for constructing the spliced section. The next two columns indicate the original depth and the thickness of this interval in the hole that it came from (i.e., the original hole). The spliced depth indicates the new depth of this interval in the composite section.

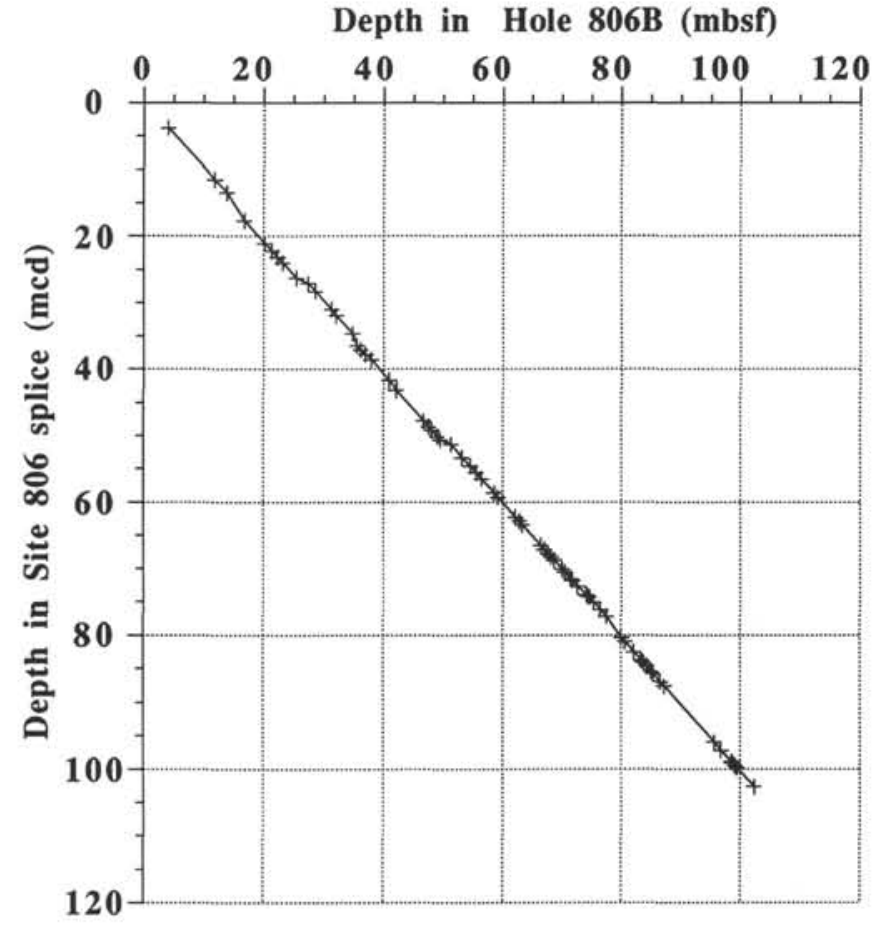

Figure 4. Comparison of depth of events identified in Table 1 in Hole 806B with their final position in the spliced section. $\mathrm{mcd}=$ meters composite depth.

806 GRAPE record using the age model based on Shackleton et al. (1990) (Fig. 7) indicates that there are still problems with the Site 806 stratigraphy. Further effort, particularly the improvement of the stratigraphy through tuning, will be necessary to make final adjustments to the Site 806 time scale presented here and in the accompanying paper by Jansen et al. (this volume).

\section{DISCUSSION}

\section{Origin of the GRAPE Signal}

The clear presence of Milankovitch frequencies in the GRAPE record implies that paleoceanographic information is contained in this record. Given the high resolution of the GRAPE data, it is well worth exploring the origin of this signal. In the central and eastern equatorial Pacific, where the sediments are dominated by two components (biogenous silica and biogenous carbonate), the paleoceanographic
Table 3. Stratigraphy used for Site 806 analyses.

\begin{tabular}{lrrrr}
\hline \multicolumn{1}{c}{ Event } & $\begin{array}{c}\text { Depth in } \\
\text { Hole } 806 \mathrm{~B} \\
(\mathrm{~m})\end{array}$ & $\begin{array}{c}\text { Spliced } \\
\text { depth } \\
(\mathrm{m})\end{array}$ & $\begin{array}{c}\text { Paleomagnetic } \\
\text { age } \\
(\mathrm{Ma})\end{array}$ & $\begin{array}{c}\text { Shackleton } \\
\text { age } \\
(\mathrm{Ma})\end{array}$ \\
\hline LO P. lacunosa & 9.01 & 8.76 & 0.46 & 0.460 \\
LO D. macintyrie & 34.40 & 34.33 & 1.45 & 1.603 \\
LO D. brouweri & 43.51 & 44.65 & 1.89 & 1.950 \\
OA D. triradiatus acme & 45.65 & 46.79 & 2.07 & 2.211 \\
LO D. pentaradiatus & 54.68 & 54.75 & 2.39 & 2.521 \\
Stage 100 & 55.33 & 55.37 & - & 2.535 \\
Stage 104 & 57.31 & 57.40 & - & 2.600 \\
Stage 116 & 64.41 & 64.50 & - & 2.870 \\
LO R. pseuoumbilica & 94.75 & 95.17 & 3.56 & 3.740 \\
LO C. acutus & 148.00 & 148.72 & 4.60 & 4.830 \\
LO D. quinqueramus & 162.50 & 162.93 & 5.00 & 5.250 \\
\hline
\end{tabular}

Notes: Ages <2.6 Ma are from Shackleton et al. (1990) and Shackleton (pers. comm., 1991). Ages for datums older than $2.6 \mathrm{Ma}$ were obtained by adding $5 \%$ to paleomagnetic ages. $\mathrm{LO}=$ last occurrence and $\mathrm{OA}=$ optimum abundance.

significance of the GRAPE signal has been well established. In this environment the saturated bulk density variations recorded in the GRAPE record are a direct result of changes in the calcium carbonate content (Fig. 9A). As the carbonate content varies in response to changes in dissolution or productivity, the contrast in grain density and packing mode between biogenous carbonate and biogenous silica creates large differences in saturated bulk density (Mayer, 1979).

If we look at the carbonate-density data pairs in the vicinity of Site 806, however, we do not find a significant relationship (Fig 9B). To explore the origin of the density variations on the Ontong Java Plateau, we use a piston core (PC74) collected on the site survey cruise (Mayer et al., this volume), close to the depth of Site 806 $(2547 \mathrm{~m})$ and for which we have multiple physical properties measurements on the same sample. This removes the need for interpolation in comparing physical property relationships and allows us to evaluate the interrelationships statistically.

In contrast to the eastern and central equatorial Pacific, the sediments of the upper reaches of the Ontong Java Plateau are almost entirely biogenous carbonate. In this environment, even pervasive dissolution does not change the percentage carbonate significantly (e.g., Johnson et al., 1977), and very little variability is present in the carbonate content of the sediments at Site 806 (Berger et al., in press). Therefore, not enough range in the variability of the carbonate content exists to create the packing and grain-density changes necessary to generate correlatable saturated bulk-density contrasts.

A stronger relationship can be found, however, if we compare saturated bulk density with changes in grain size (expressed as percent sand; Figs. 10A and 10B). Examination of the two curves shows a clear antithetical relationship, one that is more clearly expressed in a 


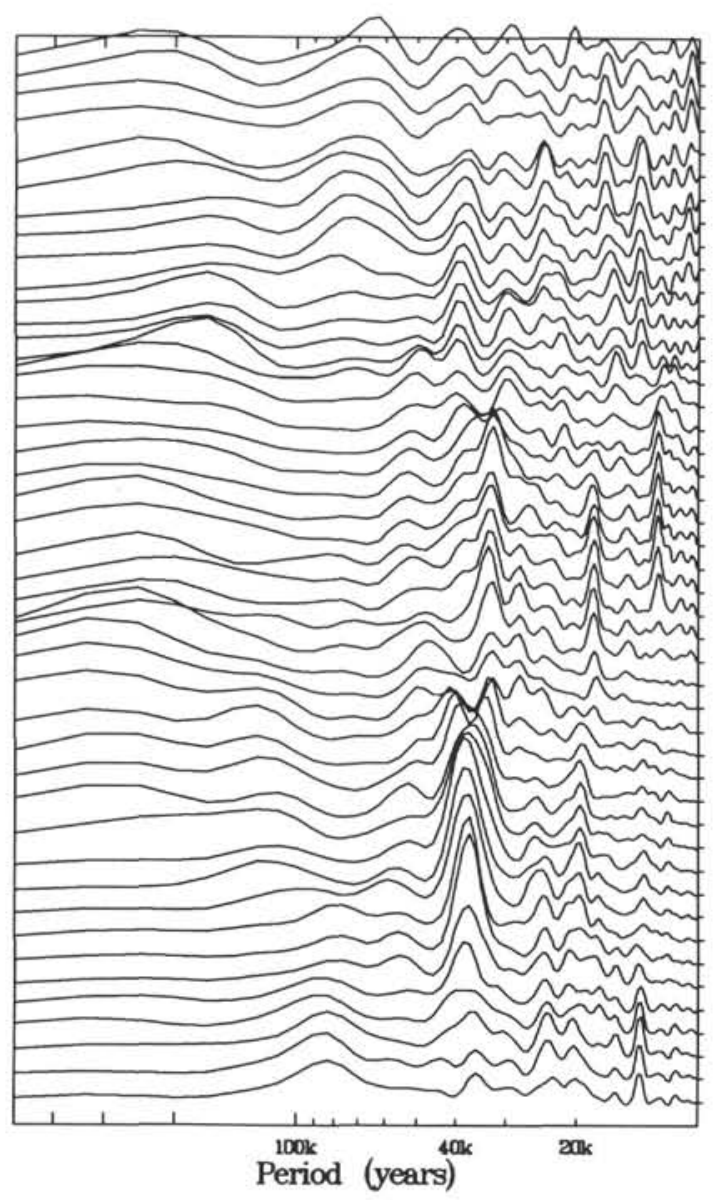

3.960

3780

3600

3.420

3240

3060

2880

2700

2520

2340

2180

1.980

1.800

1.620

1.440

1280

1000

0.500

0.720

0.540

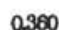

0.180

0.000

Figure 5. Evolutionary spectra for the period from 4.98 to $0 \mathrm{Ma}$ using only the biostratigraphic datums presented in Table 3 . Window is $900,000 \mathrm{yr}$ with $90 \%$ overlap (see Fig. 2 for details).

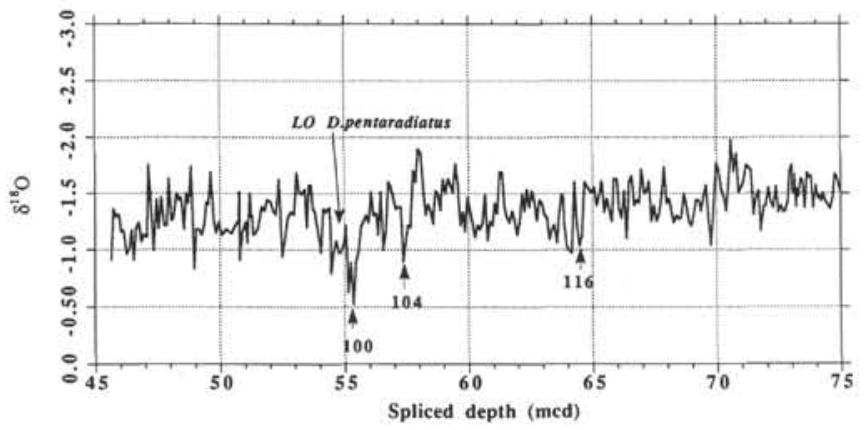

Figure 6. Oxygen isotope record for the interval between 45 and 75 med (Site 806 ) showing events correlated with isotope stages 100,104 , and 116 of Raymo et al. (1989, 1990). See Jansen et al. (this volume) for details of isotopic record. mcd $=$ meters composite depth.

comparison of the curves than in the regression relationship. The reason for the lack of a stronger statistical relationship is the presence of variability at a range of wave lengths (periodicities) and with varying phase relationships, indicating that a complex set of factors are responsible for this variability. This can be demonstrated by applying a 5-pt Gaussian smooth to both the grain-size and density data and comparing these curves (Figs. 11A and 11B). Here, the inverse relationship between the two data sets is very pronounced, and a simple regression nicely expresses this relationship (Fig. 11B).

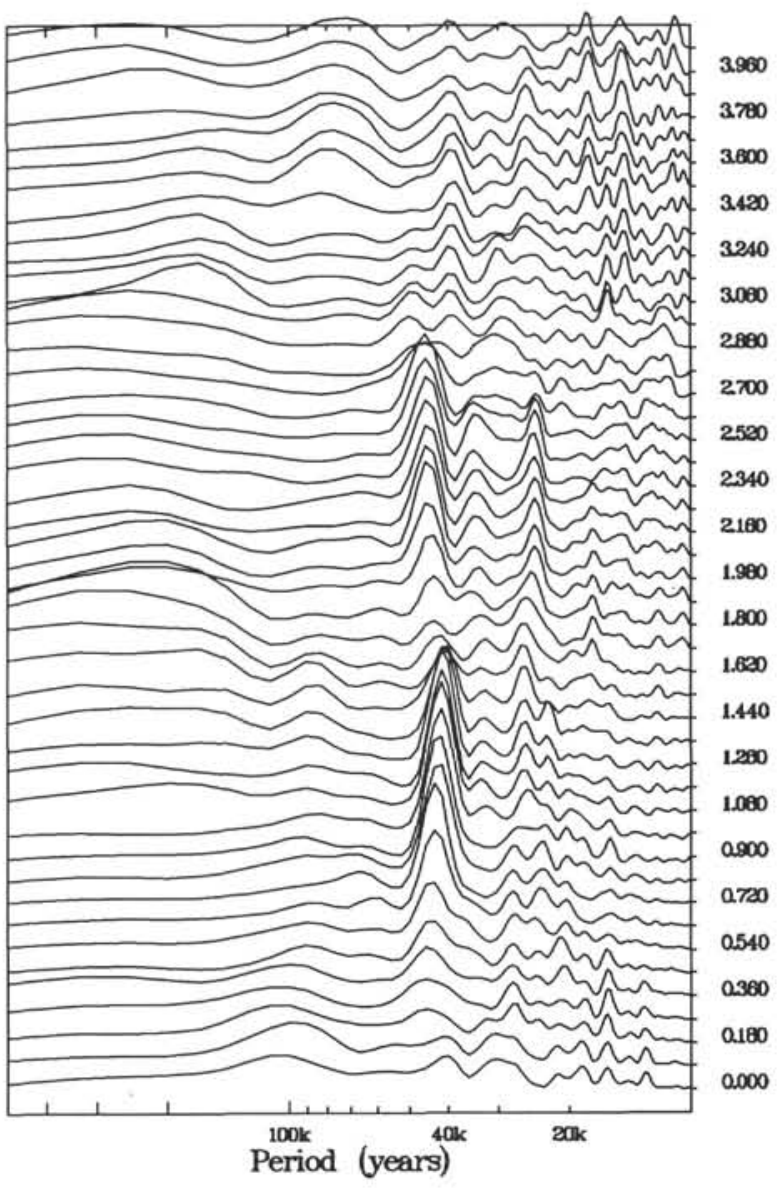

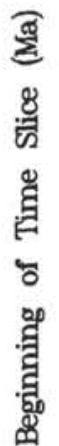

Figure 7. Evolutionary spectra for the period from 4.98 to $0 \mathrm{Ma}$ using the biostratigraphic datums plus isotopic event ages of Shackleton et al. (1990). See Table 3.

From Figure 11 it is clear that the GRAPE signal, in large part, responds to changes in grain size. It is also clear that, as percent sand increases, saturated bulk density decreases. This is the reverse of the standard relationship established for most marine sediments (Hamilton, 1974), and understanding the cause of this relationship may provide insight into the paleoceanographic significance of the GRAPE signal. The standard relationship of increasing density with increasing grain size is established for marine sediments that are dominated by material of terrigenous origin. The larger components of this material are dominated by solid quartz spheres; therefore, as grain size increases, the saturated bulk density of the system increases. The predominantly hollow spheres of the sediments of the upper reaches of the Ontong Java Plateau, however, behave quite differently. In a study of the physical properties of surficial sediments of the Ontong Java Plateau, Johnson et al. (1977) were unable to find a relationship between grain size and density, attributing this to the complications caused by intraparticle porosity in the foraminifer tests.

It is important to note that Johnson et al. (1977) studied the effect of dissolution on the physical properties of Ontong Java Plateau sediments and their data set examined the relationships between samples from various depths along the plateau. A look at their data reveals that, although dissolution as a result of depth has a clear and significant effect on the grain-size distribution of Ontong Java Plateau sediments (Fig. 12A), the grain-size changes caused by dissolution do not seem to change significantly the saturated bulk density of the sediment (Fig. 12B). On the other hand, the grain-size changes we see in PC74 and at Site 806 do appear to have a significant effect on the saturated bulk density. 
Age (Ma)

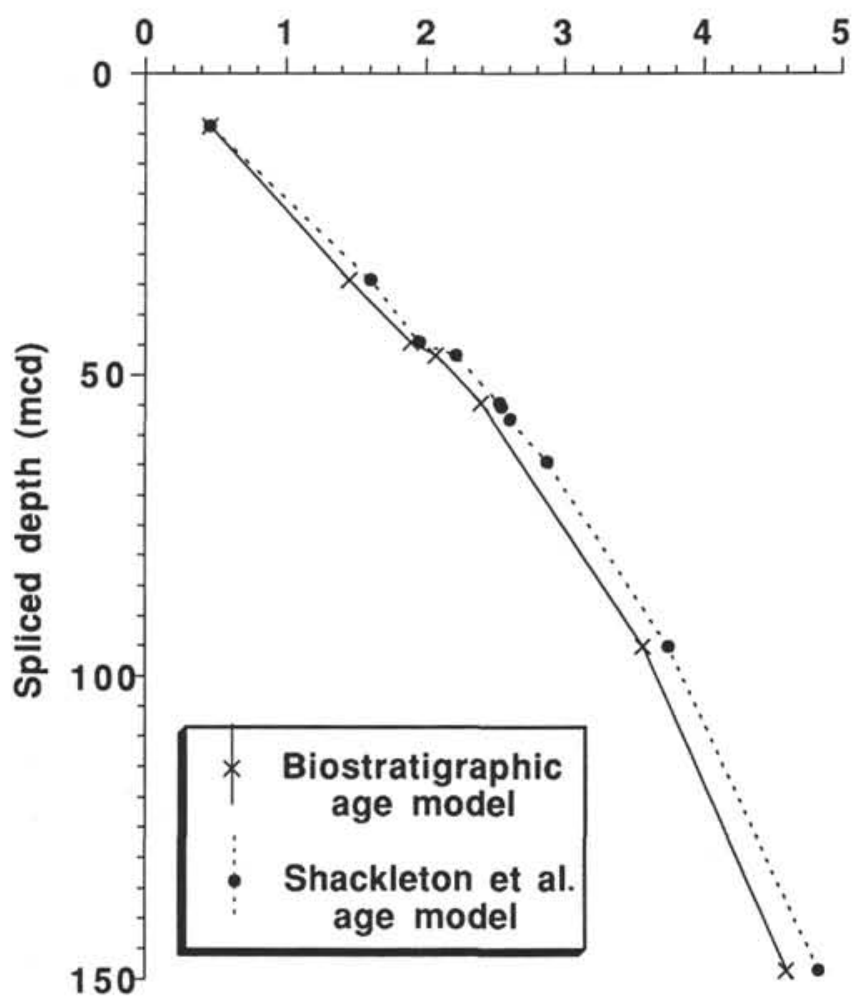

Figure 8. Plot of the differences in the age-depth relationships for the various age models evaluated. mcd $=$ meters composite depth .

The mechanism proposed for the change in grain size with dissolution is the breakdown of large, whole foraminifer tests into fragments and thus the transfer of intraparticle porosity to interparticle porosity. Although the breakdown of particles (and thus the decrease in grain size) seems quite efficient (e.g., Fig. 12A), the fragments maintain an open structure that does not change the saturated bulk density of the system significantly. At PC74 and Site 806, well above the local lysocline (Wu and Berger, 1991), dissolution should not play a major role. We contend that the changes in grain size at Site 806 are the result of current winnowing that removes the fines and leaves a greater percentage of the hollow, unbroken, and largely unfilled foraminifers. This mechanism would show an inverse relationship between grain size and saturated bulk density. Thus, we have identified a "dissolution signal" in which grain size varies without significant effect on saturated bulk density and a "winnowing signal" in which grain-size changes do effect the saturated bulk density. The sediments from the upper part of the Ontong Java Plateau clearly show the "winnowing signal."

We must be careful to acknowledge that we cannot dismiss the potential role of productivity in creating changes in grain size (e.g., the foraminifer/nannofossil ratio). Although conclusions about the role of productivity will have to await detailed analyses of carbon isotopes and other sediment characteristics, spectral evidence (discussed below) leads us to hypothesize that the grain-size (and thus GRAPE) record at Site 806 is caused, in large part, by changes in winnowing. This is consistent with the findings of $\mathrm{Wu}$ and Berger (1991), who examined a series of piston and box cores from the Ontong Java Plateau, found no evidence of significant fragmentation in those samples taken above the lysocline, and concluded that the grain-size signal on the shallow part of the plateau is a winnowing signal.

Further insight into the origin of the grain size signal can be gained from Figure 11. The smoothed grain-size and saturated bulk-density
A

\section{Carbonate $(\%)$}

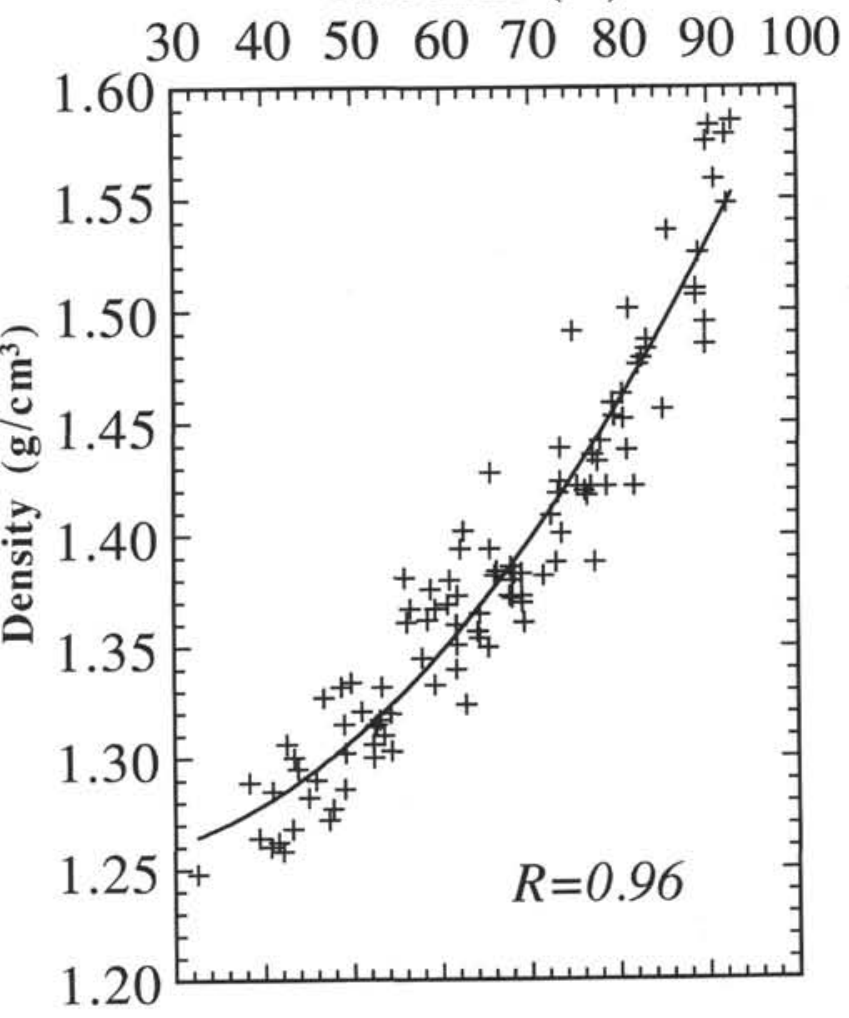

B

Carbonate $(\%)$

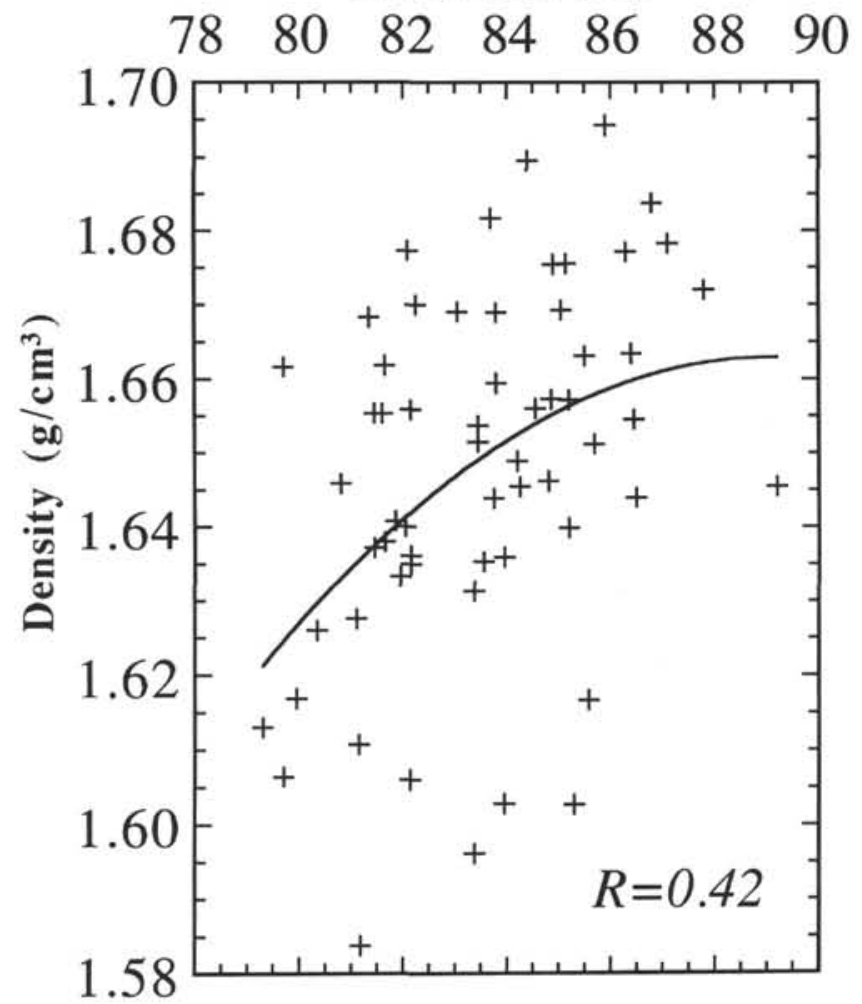

Figure 9. A. Percent carbonate-saturated bulk-density relationship from SIO Core PLDS 133 at 4500-m water depth in the central equatorial Pacific. Line is second-order fit. B. Percent carbonate-saturated bulk-density relationship from SIO Core RNDB 74 at $2540 \mathrm{~m}$ on the Ontong Java Plateau. Line is second-order fit. 


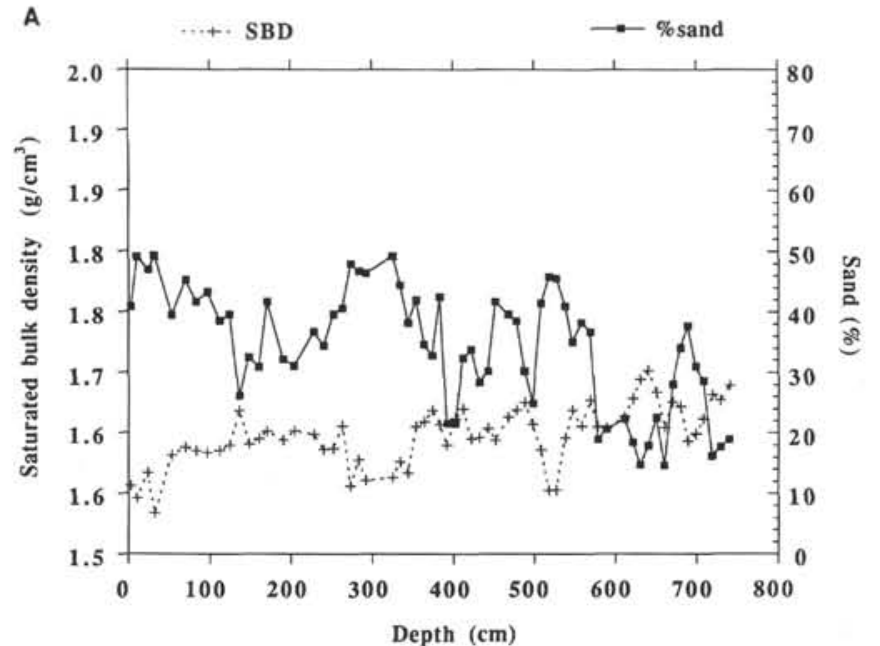

B

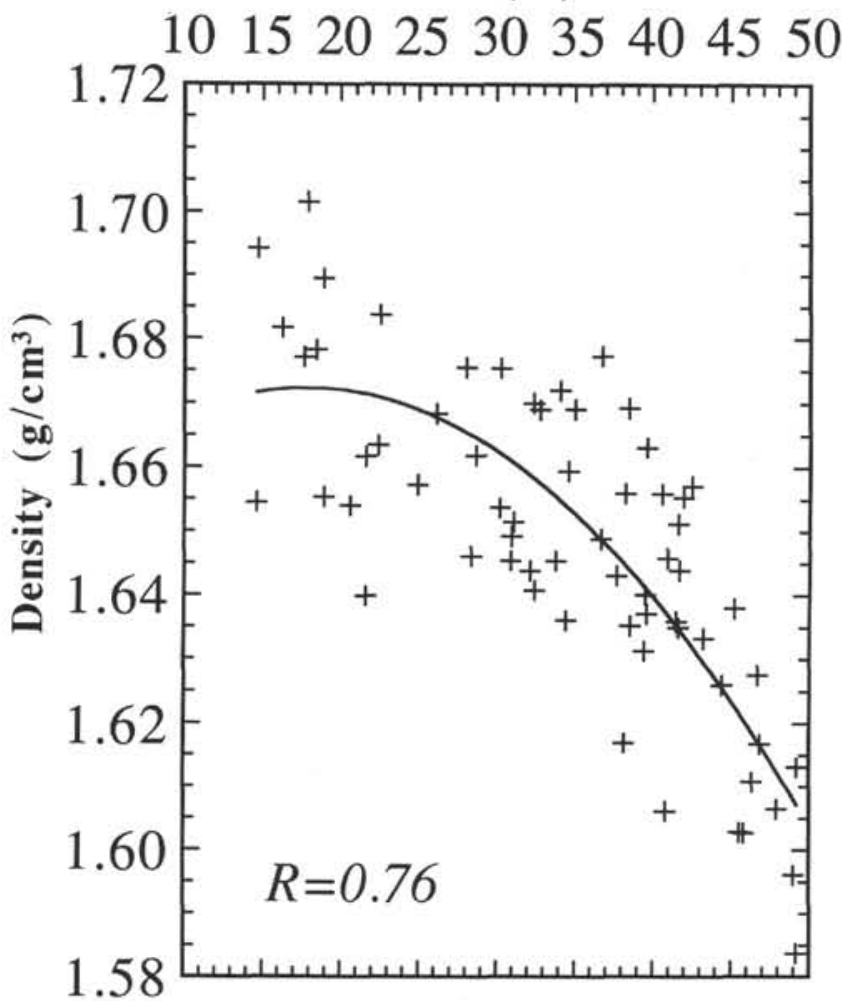

Figure 10. A. Comparison of saturated bulk density (SBD, measured by constant volume method on discrete samples) with the percent sand data on the same sample from SIO Core RNDB 74 on Ontong Java Plateau. B. Regression of saturated bulk density and percent sand data from SIO Core RNDB 74. Line is second-order fit.

curves show several large-amplitude cycles that have the dominant antithetical relationship. A preliminary stratigraphy for this core $(\mathrm{L}$. Tauxe, pers. comm., 1992) reveals that these cycles are 100-k.y. eccentricity cycles and thus for at least the last 250-300 k.y. the "winnowing effect" is dominated by a $100-k . y$. periodicity with increased grain size correlating with glacial times (typically with a lag of $10-15 \mathrm{k} . \mathrm{y}$.) and implying that the grain-size signal is responding to climatic forcing in a way similar to global ice volume. The association of increased grain size (winnowing) with glaciations is also consistent

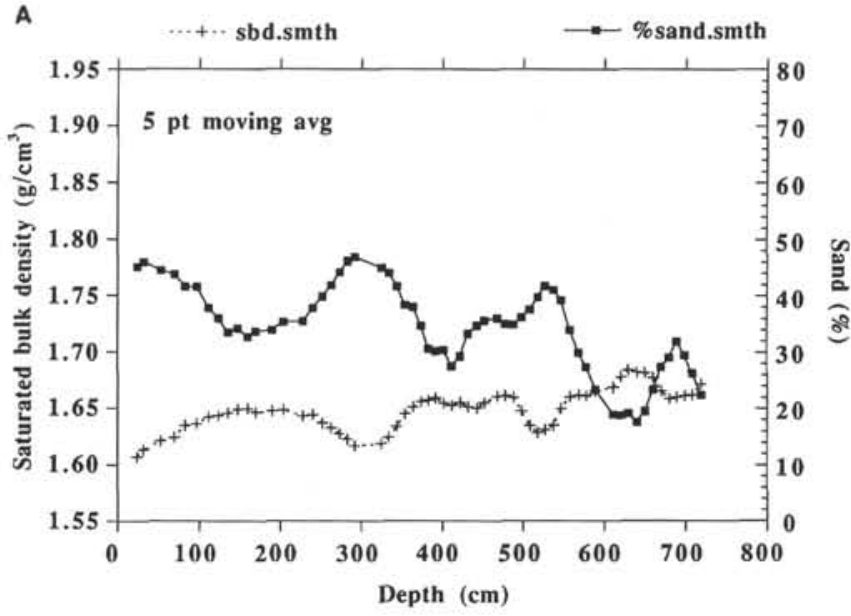

B

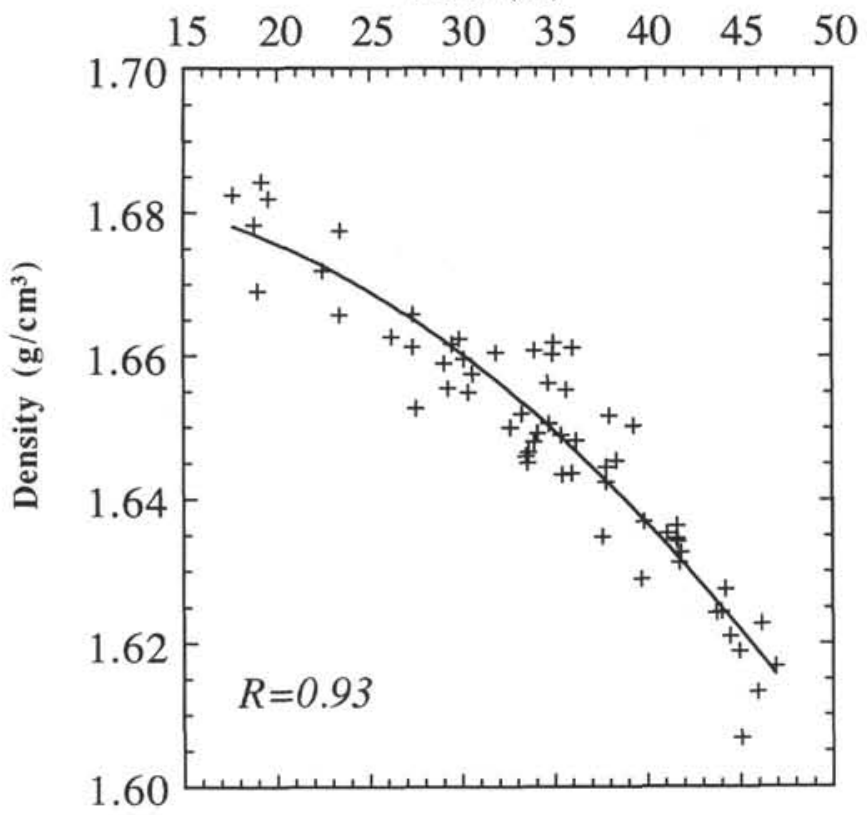

Figure 11. A. Comparison of smoothed (with 5-pt moving average) saturated bulk density and smoothed (with 5-pt moving average) percent sand data from SIO Core RNDB 74. B. Regression of smoothed saturated bulk density and smoothed percent sand data from SIO Core RNDB 74. Line is second-order fit.

with the conclusions of Wu and Berger (1991). We will explore this in more detail when we compare the grain-size and oxygen isotope record in the deeper part of the section.

\section{The Frequency Domain}

Extending the conclusions drawn from the piston core to the long, high-resolution time series achievable with GRAPE analyses of ODP cores, we see that the basic trends established for the upper few thousand years continue (with some modifications). In the following, we will restrict our discussion to the time interval between 2 and $5 \mathrm{Ma}$, the interval over which we also have oxygen isotope data and an important transitional period in the evolution of global climate (see the companion paper, Jansen et al., this volume). Figure 13 shows a comparison of GRAPE density and grain size (expressed as percent sand) for the interval 2-5 Ma at Site 806 . The inverse relationship between grain size and percent sand is clear, though it 
A

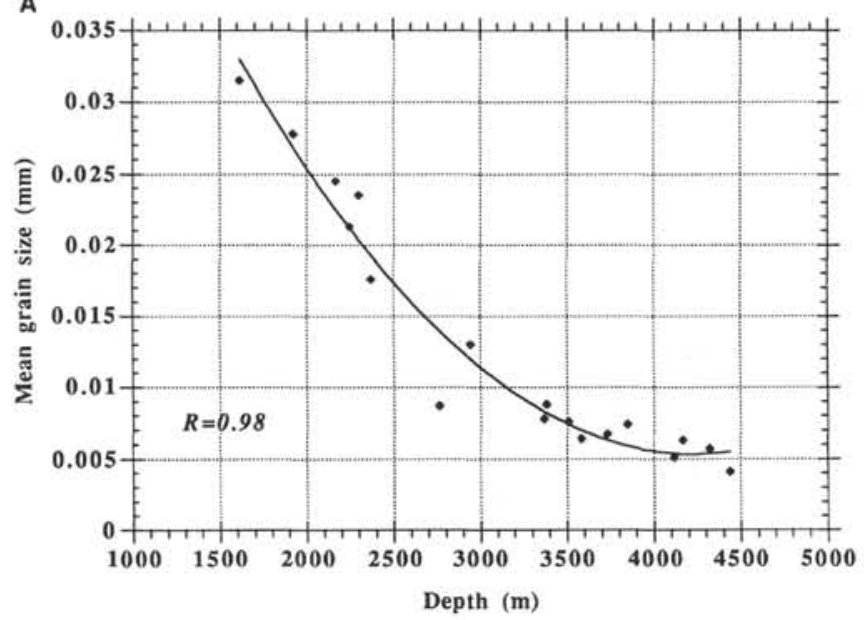

B

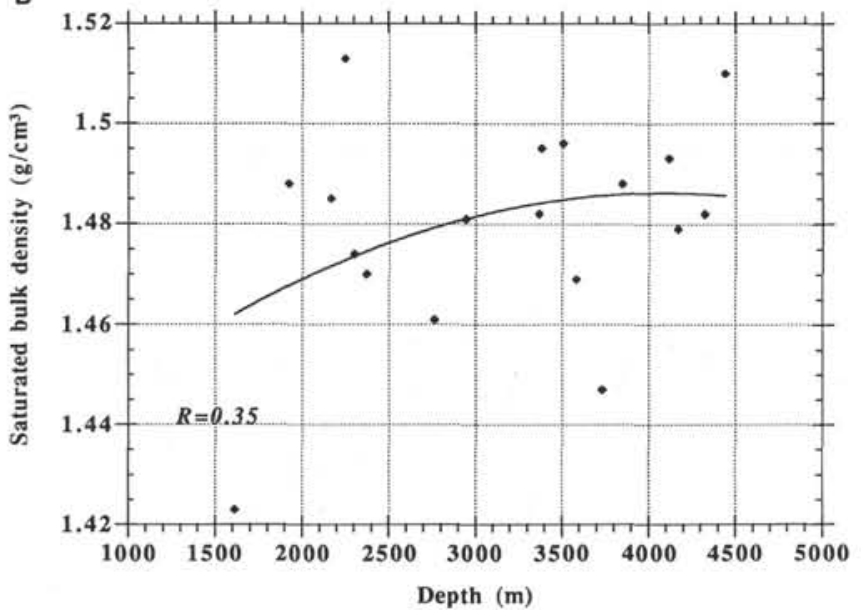

Figure 12. A. Relationship between mean grain size and depth from surficial samples of Ontong Java Plateau box cores (from Johnson et al., 1977). Line is second-order regression. B. Relationship between saturated bulk density and depth for same samples as in Figure 12A. Line is second-order regression.

is also apparent that the frequency of modulation of these changes is different from the dominant $100-k . y$. cyclicity found in the upper 200-300 k.y. of PC74. In the older interval, the dominant cyclicity appears to be approximately $40 \mathrm{k} . \mathrm{y}$. (the Milankovitch tilt period), consistent with the well-documented increase in 100-k.y. climatic response after about 900 k.y. b.p. (e.g., Pisias and Moore, 1981; Ruddiman et al., 1986) and apparent in the evolutionary spectrum of the GRAPE record (Fig. 7).

Given our understanding that in the upper portions of the Ontong Java Plateau the GRAPE signal is produced by grain-size changes, we can use the oxygen isotope record (measured on Globigerinoides sacculifer; Jansen et al., this volume) to explore the paleoceanographic significance of this signal. A comparison of the grain-size curve with the $\delta^{18} \mathrm{O}$ record reveals a much more complex picture than that for PC74 (Fig. 14). Although a visual comparison of these two data sets seems to imply a generally inverse relationship, the relationship is quite complex and difficult to discern. To attempt to extract the nature of this relationship, we will look at the spectral components of these records.

A basic assumption of the spectral techniques used to evaluate the frequency content of paleoclimatic records is stationarity. This has been fairly well established for the time interval from 0 to $400 \mathrm{ka}$, but there is growing evidence (including that presented here) that major changes have been taken place in the response of the climate system at several times during the last $5 \mathrm{~m}$.y. Given the nonstationarity of the long-term paleoclimatic records we have, as a first pass, divided the 3-m.y. records that we are analyzing into 1-m.y. partitions and analyzed each of these separately. This is a division of convenience; given the uncertainties remaining in the time scale (see discussion above), we use spectral techniques here as an exploratory tool rather than as a detailed analytical tool. Once a time scale is finalized, these exploratory efforts can provide a guide to dividing the time series into carefully selected, stationary intervals and the spectral approach used for detailed examinations of coherency and phase between the various components of the system.

Cross-spectra between the grain-size record and the oxygen isotope record indicate that in the interval 2-3 Ma significant coherence exists in each of the Milankovitch bands (as well as at approximately 60 and 30 k.y.; Fig 15); in the intervals 3-4 and 4-5 Ma, less coherence is present in the obliquity band. The reason for this is evident in an examination of the evolutionary spectra for grain size and oxygen isotopes (Figs. 16A and 16B). It can be seen that variance in the obliquity band is well developed in both records in the interval from 2 to about $2.8 \mathrm{Ma}$. Before about $2.8 \mathrm{Ma}$, however, the obliquity signal is greatly reduced (almost absent) in the oxygen isotope record, although it remains reasonably strong throughout the grain-size record. Before $3 \mathrm{Ma}$, a clear shift to higher frequencies is present in the isotope record (Fig 16; see discussion in Jansen et al., this volume); although an increase in variance in the high frequencies in the grain-size record is present, it is nowhere near as strong as that in the oxygen isotope record. It is important to note that these two data sets were measured on the same samples, and thus these differences in response are real and not an artifact of sampling. The evolutionary spectrum of the GRAPE record (which is not based on the same samples and thus subject to sampling artifacts) is much closer in appearance to the grain-size record, consistent with our conclusion of a straightforward relationship between grain size and density.

We can view this phenomenon in another way and gain insight into the relative response of grain size and the isotopic record by looking at these values filtered at the obliquity frequency (Fig. 17). It is clear from this figure that in the obliquity band there is, for the most part, the previously established inverse relationship between grain size and isotopes. In addition, comparison of the amplitude of the individual peaks (the envelope of the curves) reveals high coherence from 2 until about $3 \mathrm{Ma}$; from 3 to $5 \mathrm{Ma}$ the grain-size curve continues to display large-amplitude 41-k.y. fluctuations whereas the isotopic record does not.

Thus, we continue to see a "winnowing" signal associated (for the most part) with isotopically heavy intervals. In the youngest part of the record (PC74: 0-300 k.y.), these fluctuations have dominant $100-k . y$. (eccentricity) periodicity. In the interval from 2 to approximately $3 \mathrm{Ma}$, the oxygen isotope and grain-size signals are coherent and dominated by $41-k . y$. (obliquity) periodicities. Before this time, however, the grain-size (and GRAPE) signal continues to be dominated by the obliquity band whereas the isotope record displays a shift to precession-related frequencies.

The dominance of obliquity-related frequencies in the GRAPE and grain-size record is significant in that it implies that whatever is driving these responses is a high-latitude phenomenon (Short et al., 1990). Given the evidence suggesting that the GRAPE and grain-size records are representative of winnowing, we conclude that these signals are a response to changes in deep-water formation at high latitude. This response appears to be enhanced during times of greater global ice volume and particularly with the onset of Northern Hemisphere glaciation, although it was established well before the onset of major Northern Hemisphere glaciation (Figs. 15 and 17). Wu and Berger (1991) discuss several possible mechanisms for enhancing winnowing during glaciations: (1) enhanced thermohaline circulation; (2) increased benthic storm activity because of enhanced northsouth thermal gradients; (3) increased magnitude of tidal motion because of less energy dissipation on the shelves; and (4) increased 

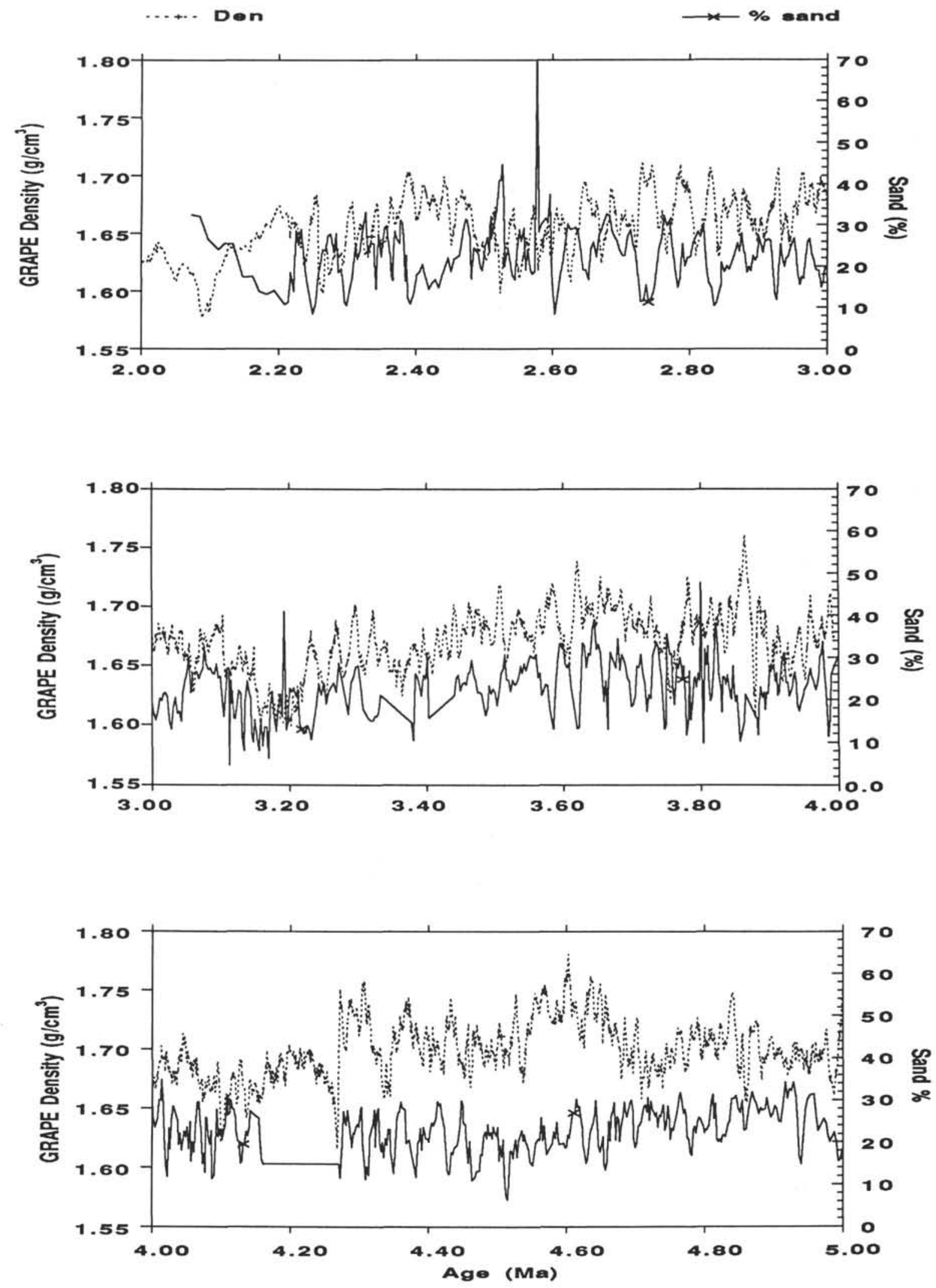

Figure 13. Time series of GRAPE density (dashed line) and percent sand (solid line) for interval between 4.8 and $2 \mathrm{Ma}$. 

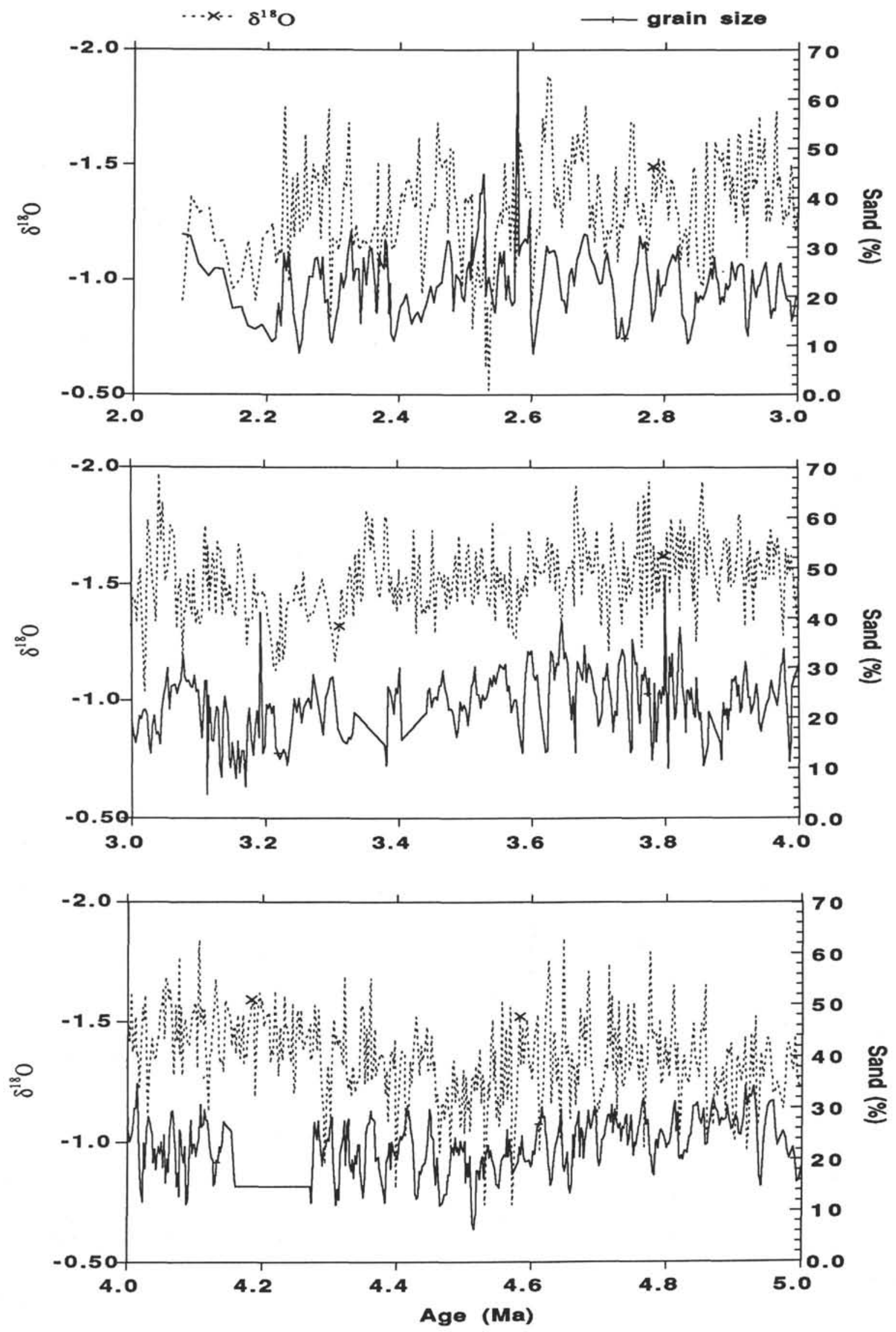

Figure 14. Time series of $\delta^{18} \mathrm{O}$ (solid line) and percent sand (dashed line) for the interval between 4.8 and $2 \mathrm{Ma}$. 
A
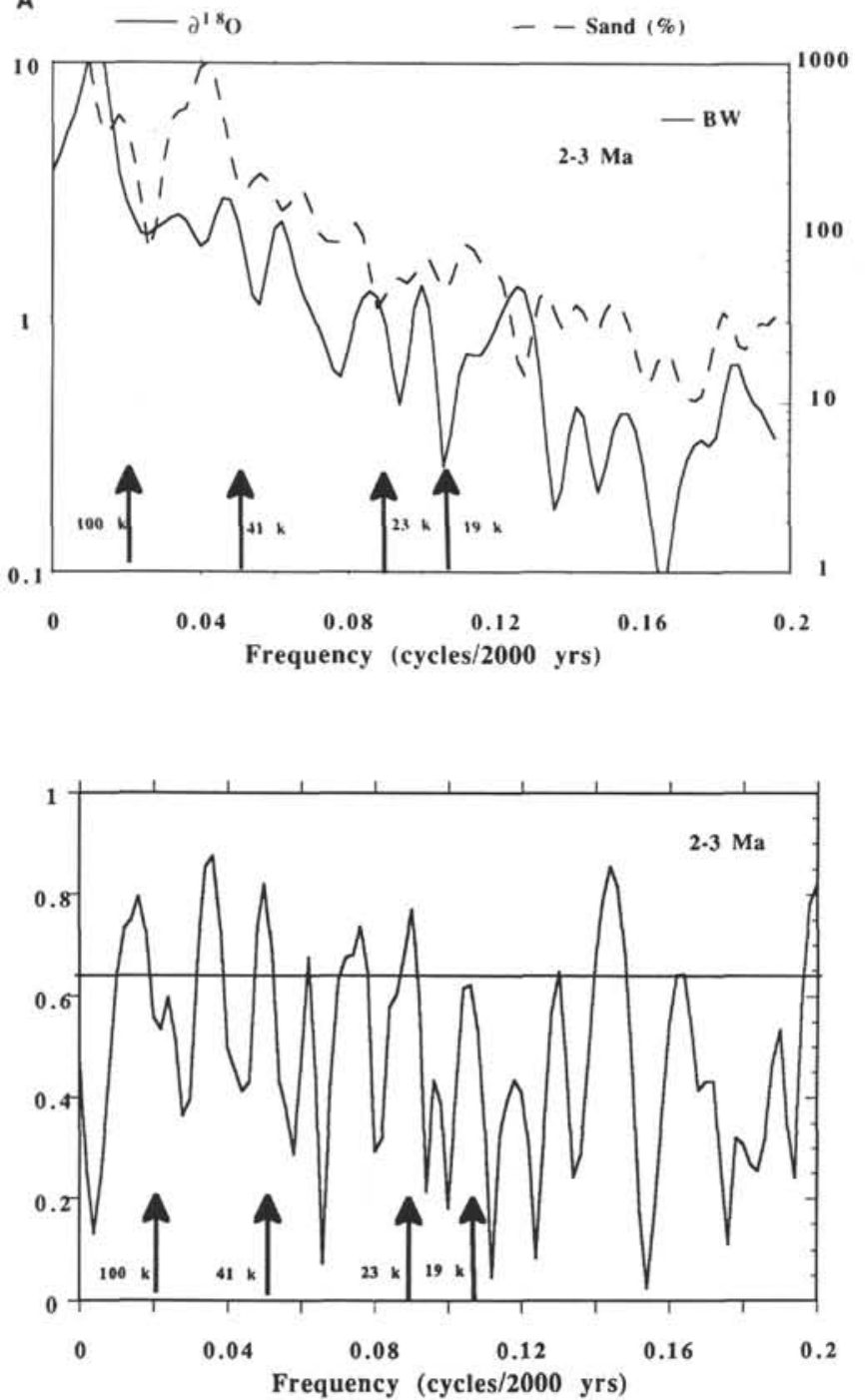

B
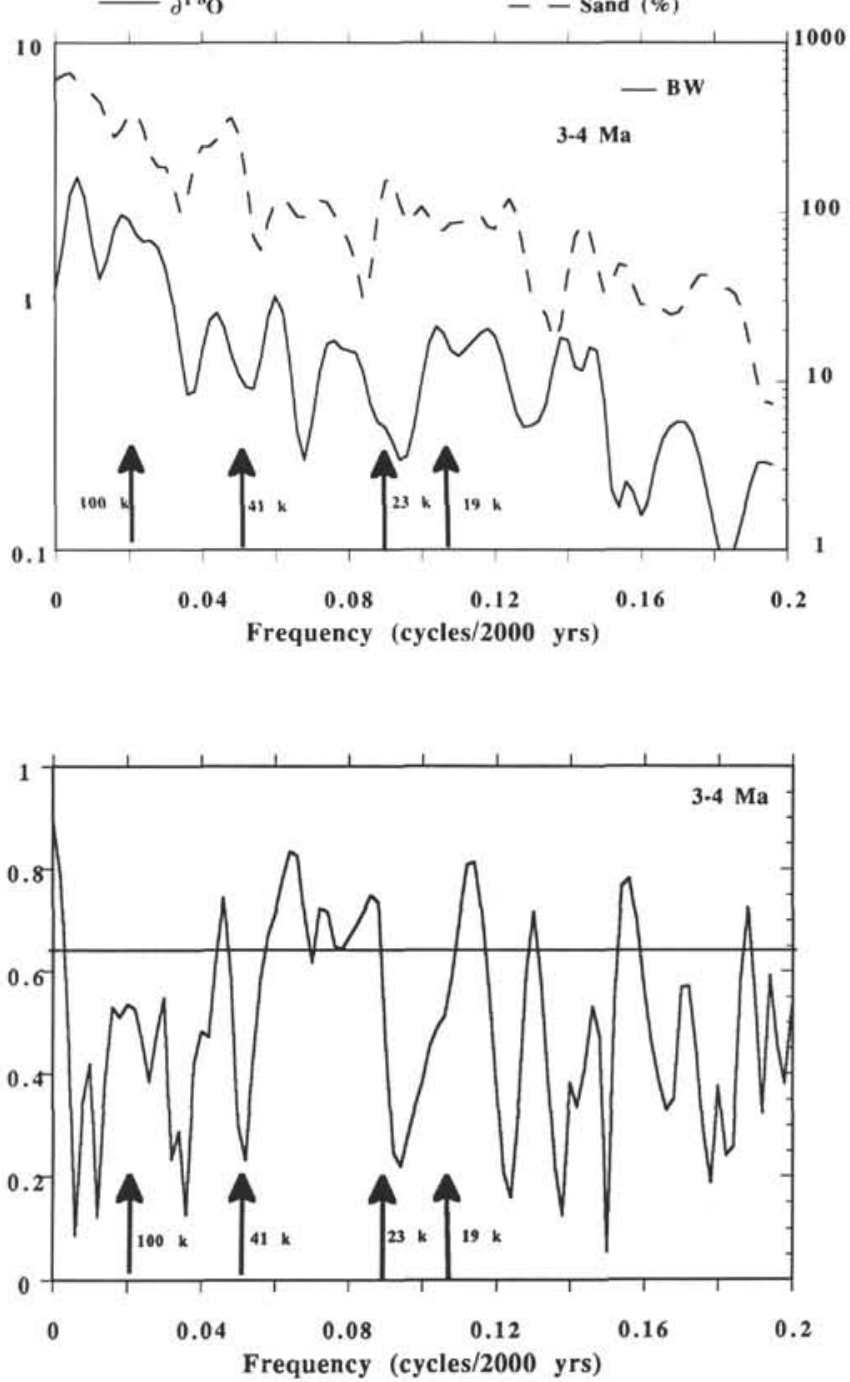

Figure 15. Coherency (bottom plot) and variance spectra calculated from $\delta^{18} \mathrm{O}$ (solid line) and grain size (dashed line) for intervals 2-3 (A), 3-4 (B), and 4-5 (C) Ma. Variance is plotted on an arbitrary log scale; note that the \% sand axis is 2 orders of magnitude larger than $\delta^{18} \mathrm{O}$. Coherency is plotted on a hyperbolic arc-tangent scale with the horizontal line indicating a 95\% significance level. Frequency axis is in cycles per sample interval. Sample interval is 2000 yr. Major Milankovitch periods are indicated by arrows.

energy of earthquake-generated tsunamis, again caused by less dissipation on the shelves. If our suggestion that the winnowing-isotope relationship was established well before the onset of major Northern Hemisphere glaciation is correct, it implies that the mechanism is related (at least in part) to thermohaline circulation or thermal gradients as opposed to major changes in shelf area.

The dominance of the obliquity period in the GRAPE and grain-size records also supports our suggestion that the signal is the result of winnowing rather than productivity. Although changes in productivity may result in increases in the foraminifer-to-coccolith ratio and thus have a grain-size and density effect similar to that of winnowing, we would expect that productivity changes may be related to more local, surface-water (wind-driven) phenomena and thus be more closely associated with the precessional frequencies. It is possible that equatorial productivity can be modulated by high-latitude forcing through variations in the nutrient content of upwelling waters. Boyle (1988) has shown that intermediate-water nutrients were reduced during the last glacial maximum. Stripping intermediate waters of nutrients may reduce productivity in areas where intermediate waters upwell and thus provide an obliquity modulated equatorial productivity signal. It is unlikely, however, that this mechanism would apply to the western equatorial Pacific where a deep, stable thermocline would tend to limit the mixing of intermediate waters into the photic zone.

The fact the GRAPE record may be recording an oceanwide deep-water phenomenon is also supported by comparison of the evolutionary spectrum of the GRAPE record from Site 806 to that of DSDP Site $573,6500 \mathrm{~km}$ to the east in the central equatorial Pacific (Figs. 18A and 18B). The GRAPE record in the deep, central equatorial Pacific (about $4500 \mathrm{~m}$ ) is dominantly the result of preservation cycles (Mayer, 1991) and thus records changes in deep-water behavior. Striking similarities exist between the two records, particularly the noticeable increase in 41-k.y. variance at about $1.4 \mathrm{Ma}$. We expect that the similarities between these records will be even greater when a final time scale is developed for Site 806. The similarities in the behavior of the 41-k.y. signal between these two sites implies that both sites are responding to basinwide (at least) changes in deep water. 
C
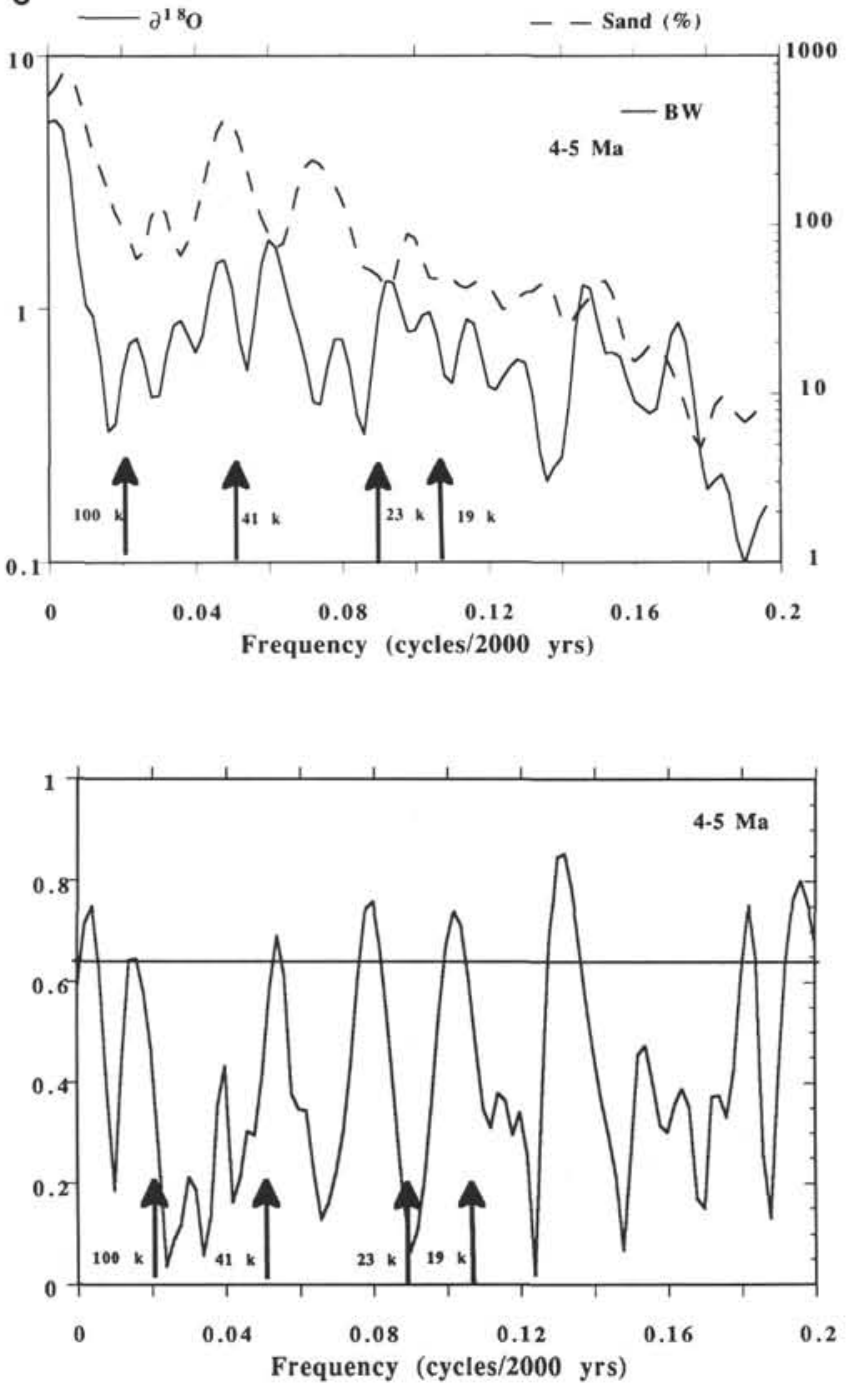

Figure 15 (continued).

\section{CONCLUSIONS}

The unique topographic and geographic setting of the Ontong Java Plateau has made it the focus of numerous paleoceanographic studies. We examined the gamma-ray attenuation porosity evaluator (GRAPE) record from Site 806 at $2520 \mathrm{~m}$ on the Ontong Java Plateau to explore its potential as a paleoceanographic tool. The GRAPE provides a very rapid and nearly continuous record of saturated bulk density vs. depth in core. When combined with multiple holes at a single site, the GRAPE data allowed us to evaluate the continuity of the recovered cores and to splice together a composite section. If the changes in saturated bulk density can be related to oceanographic or climatic parameters, the GRAPE data can also provide a rapid, long, and very high-resolution record of paleoceanographic change.

Evaluation of the GRAPE record at Site 806 revealed gaps between successive cores in any one hole; using data from multiple holes, we spliced together a composite section for the upper $165 \mathrm{~m}$ (approximately 0-5 Ma). The lack of offset in the core breaks (i.e., in-between successive 9.5-m cores) from hole to hole at Site 806 made splicing difficult and the results are not unambiguous. The composite section was converted to a time series by using the best biostratigraphy available and supplementing this with oxygen isotope datums for the interval between 2 and $5 \mathrm{Ma}$. The continuity and high resolution of the GRAPE data permit the construction of evolutionary spectra that clearly indicate the presence of Milankovitch frequencies throughout the record. We chose a final age model that produced evolutionary spectra most consistent with a Milankovitch model but have not, as yet, spectrally tuned the data.

To evaluate the paleoceanographic significance of the GRAPE record in this environment, we looked at physical properties interrelationships from a piston core (where we have multiple parameters measured on the same sample) near Site 806. Unlike the central and eastern equatorial Pacific, where GRAPE (saturated bulk density) changes are directly linked to changes in carbonate content, variations in carbonate content in the shallow parts of the Ontong Java Plateau are not large enough to cause changes in density. Instead, saturated bulk-density fluctuations appear to be related to changes in grain size, with increases in grain size corresponding to decreases in saturated bulk density. This relationship is the reverse of the general trend for terrigenously derived marine sediments and the result of the predominance of hollow foraminifers in Ontong Java Plateau sediments. Previous studies of Ontong Java Plateau box cores have revealed that dissolution in this environment results in the breakdown of hollow spheres (foraminifers) into fragments that have significant effect on the grain size but limited effect on the saturated bulk density- "the dissolution effect." In the shallow portions of the plateau, we see changes in grain size associated with changes in saturated bulk density. We attribute this relationship to the removal of the finegrained component by bottom-water activity while leaving the hollow spheres untouched-"the winnowing effect." In the shallow depths above the lysocline on the Ontong Java Plateau, the grain-size signal is dominated by the winnowing effect and thus there is a measurable saturated bulk-density signal associated with changes in grain size.

Examination of a piston core collected near Site 806 reveals that for the time interval between 0 and $300 \mathrm{ka}$, grain-size increases (winnowing) are associated with glaciations. Comparison of the GRAPE/ grain-size record to the oxygen isotope record for the time interval between 5 and 2 Ma reveals that density continues to be related to grain-size changes and that grain size appears to be associated with isotopically heavy intervals (though the relationship is quite complex). Unlike the 0-300 ka interval where the grain size and GRAPE record are dominated by $100-\mathrm{k} . y$. (eccentricity) variance, the interval from 2 to $5 \mathrm{Ma}$ is dominated by the 41-k.y. (obliquity) band. The response of the grain-size and GRAPE records at 41 k.y. is large and highly coherent with the oxygen isotope (ice volume) record after the onset of major Northern Hemisphere glaciations (about 2.7 Ma). Before that time, the GRAPE and grain-size records continue to show significant variance in the obliquity band whereas the oxygen isotope record shows a shift to dominant variance in the precessional frequencies.

The dominance of the obliquity band in the GRAPE and grain-size records implies that these responses are being forced at high latitude and that, although the response is significantly enhanced during times of Northern Hemisphere glaciations, it is still present before the onset of Northern Hemisphere glaciation. We suggest that the winnowing signal is related to the increased thermohaline circulation and benthic storm activity associated with the increased north-south thermal gradients resulting from climatic degradations, although a simple linear response does not seem to exist to account for Northern Hemisphere insolation. A careful examination of phase and coherency spectra between the various components may resolve many of these issues, but this must wait until spectral tuning optimizes the stratigraphic framework at this site.

\section{REFERENCES}

Backman, J., and Shackleton, N.J., 1983. Quantitative biochronology of Pliocene and early Pleistocene calcareous nannofossils from the Atlantic, Indian and Pacific oceans. Mar. Micropaleontol., 8:141-170. 
Berger, W.H., Kroenke, L.W., Mayer, L.A., Backman, J., Janecek, T., Krissek, L., Leckie, M., and Lyle, M., in press. The record of Ontong Java Plateau: main results of ODP Leg 130. Geol. Soc. Am. Bull.

Berggren, W.A., Kent, D., and van Couvering, J.A., 1985. The Neogene. Part 2: Neogene chronology and chronostratigraphy. In Snelling, N.J. (Ed.), The Chronology of the Geological Record. Geol. Soc. London Mem., 10:211-260.

Boyce, R.E., 1973. Appendix I. Physical property methods. In Edgar, N.T., Saunders, J.B., et al., Init. Repts. DSDP, 15: Washington (U.S. Govt. Printing Office), 1115-1128.

Boyle, E.A., 1988. The role of vertical chemical fractionation in controlling late Quaternary atmospheric carbon dioxide. J. Geophys. Res., 93:15,701-15,714.

Brier, C., Bennin, R., and Rona, P.A., 1969. Preliminary evaluation of a core scintillation counter for bulk density measurement in marine sediment cores. J. Sediment. Petrol., 39:1509-1519.

Evans, H.B., 1965. GRAPE - a Device for continuous determination of material density and porosity. Trans. 6th Ann. SPWLA Logging Symp., 2:B1-B25.

Evans, H.B., and Cotterell, C.H., 1970. Gamma-ray attenuation density scanner. In Peterson, M.N.A., Edgar, N.T., et al., Init. Repts. DSDP, 2: Washington (U.S. Govt. Printing Office), 442-454.

Hagelberg, T., Shackleton, N., Pisias, N., and Shipboard Scientific Party, 1992. Development of composite depth sections for Sites 844 through 854 . In Mayer, L., Pisias, N., Janecek, T., et al., Proc. ODP, Init. Repts., 138, Pt. 1: College Station, TX (Ocean Drilling Program), 79-85.

Hamilton, E.L., 1974. Prediction of deep-sea sediment properties: state-of-theart. In Interbitzen, A.L. (Ed.), Deep-Sea Sediments, Physical and Mechanical Properties: New York (Plenum), 1-43.

Harms, J.C., and Choquette, P.W., 1965. Geologic evaluation of a gamma-ray porosity device. Trans. 6th Ann. SPWLA Logging Symp., C1-C37.

Heath, G.R., Kovar, R.B., Lopez, C., and Campi, G.L., 1985. Elemental composition of Cenozoic pelagic clays from Deep Sea Drilling Project Sites 576 and 578, western north Pacific. In Heath, G.R., Burckle, L.H., et al., Init. Repts. DSDP, 86: Washington (U.S. Govt. Printing Office).

Herbert, T.D., in press. Deterministic distortions of orbital cyclicity by sedimentation: models and examples. In Orbital Forcing and Cyclic Sequences. Spec. Publ. Int. Assoc. Sedimentol.

Herbert, T.D., and Mayer, L.A., in press. Long climatic time series from sediment physical property measurements. J. Sediment. Petrol.

Imbrie, J., Hays, J.D., Martinson, D.G., McIntyre, A., Mix, A.C., Morley, J.J., Pisias, N.G., Prell, W.L., and Shackleton, N.J., 1984. The orbital theory of Pleistocene climate: support from a revised chronology of the marine $\delta^{18} \mathrm{O}$ record. In Berger, A., Imbrie, J., Hays, J., Kukla, G., and Saltzman, B. (Eds.), Milankovitch and Climate (Pt. 1): Dordrecht (D. Reidel), 269-305.

Jansen, E., Mayer, L., and Shipboard Scientific Party, 1991. GRAPE density records and density cyclicity. In Kroenke, L.W., Berger, W.H., Janecek, T.R., et al., Proc. ODP, Init. Repts., 130: College Station, TX (Ocean Drilling Program), 553-556.

Jenkins, G.M., and Watts, D.G., 1968. Spectral Analysis and Its Applications: San Francisco (Holden Day).

Johnson, T.C., Hamilton, E.L., and Berger, W.H., 1977. Physical properties of calcareous ooze: control by dissolution at depth. Mar. Geol., 24:259-277.
Kroenke, L.W., Berger, W.H., Janecek, T.R., et al., 1991. Proc. ODP, Init. Repts., 130: College Station, TX (Ocean Drilling Program).

Mayer, L.A., 1979. Deep sea carbonates: acoustic, physical and stratigraphic properties. J. Sediment. Petrol., 49:819-836. , 1991. Extraction of high-resolution carbonate data for paleoclimate reconstruction. Nature, 352:148-150.

Mayer, L.A., Shipley, T.H., Winterer, E.L., Mosher, D., and Hagen, R.A., 1991. SeaBeam and seismic reflection surveys on the Ontong Java Plateau. In Kroenke, L.W., Berger, W.H., Janecek, T.R., et al., Proc. ODP, Init. Repts., 130: College Station, TX (Ocean Drilling Program), 45-76.

Pisias, N.G., and Moore, T.C., Jr., 1981. The evolution of Pleistocene climate; a time series approach. Earth Planet. Sci. Lett., 52:450-458.

Preiss, K., 1968. Nondestructive laboratory measurement of marine sediment density in a core barrel using gamma radiation. Deep-Sea Res., Pt. A, $15: 401-407$.

Raymo, M.A., Ruddiman, W.F., Backman, J., Clement, B.M., and Martinson, D.G., 1989. Late Pliocene variations in Northern Hemisphere ice sheets and North Atlantic deep water circulation. Paleoceanography, 4:413-446.

Raymo, M.A., Ruddiman, W.F., Shackleton, N.J., and Oppo, D.W., 1990. Evolution of global ice volume and Atlantic-Pacific $\delta^{13} \mathrm{C}$ gradients over the last 2.5 m.y. Earth Planet Sci. Lett., 97:353-368.

Ruddiman, W.F., Cameron, D., and Clement, B.M., 1987. Sediment disturbance and correlation of offset holes drilled with the hydraulic piston corer: Leg 94. In Ruddiman, W.F., Kidd, R.B., Thomas, E., et al., Init. Repts. DSDP, 94, Pt. 2: Washington (U.S. Govt. Printing Office), 615-634.

Ruddiman, W.F., Raymo, M.E., and McIntyre, A., 1986. Matuyama 41,000year cycles: North Atlantic Ocean and Northern Hemisphere ice sheets. Earth Planet. Sci. Lett., 80:117-129.

Schultheiss, P.J., and McPhail, S.D., 1989. An automated $P$-wave logger for reconstructing fine-scale compressional wave velocity structures in sediments. In Ruddiman, W., Sarnthein, M., et al., Proc. ODP, Sci. Results, 108: College Station, TX (Ocean Drilling Program), 407-413.

Shackleton, N.J., Berger, A., and Peltier, W.R., 1990. An alternative astronomical calibration of the lower Pleistocene time scale based on ODP Site 677. Trans. R. Soc. Edinburgh, Earth Sci., 81:251-261.

Shackleton, N.J., and Shipboard Scientific Party, 1992. Sedimentation rates: toward a GRAPE density stratigraphy for Leg 138 carbonate sections. In Mayer, L., Pisias, N., Janecek, T., et al., Proc. ODP, Init. Repts., 138, Pt. 1: College Station, TX (Ocean Drilling Program), 87-91.

Short, D.A., Nengel, J.G., Crowley, T.J., Hyde, W.T., and North, G.R., 1990. Filtering of Milankovitch cycles by Earth's geography. Quat. Res.

Wu, G., and Berger, W.H., 1991. Pleistocene $\delta^{18} \mathrm{O}$ records from Ontong Java Plateau: effects of winnowing and dissolution. Mar. Geol., 96:193-209.

Date of initial receipt: 4 December 1991

Date of acceptance: 12 May 1992

Ms 130B-046 
A

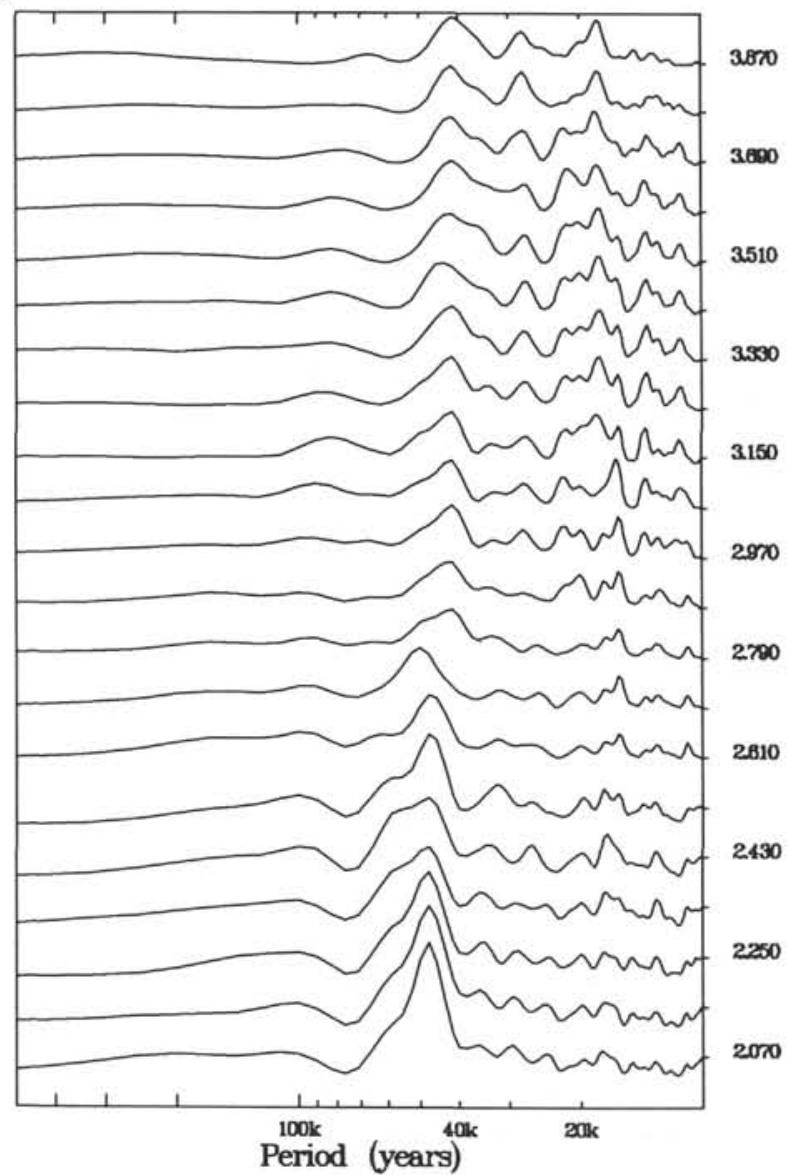

B

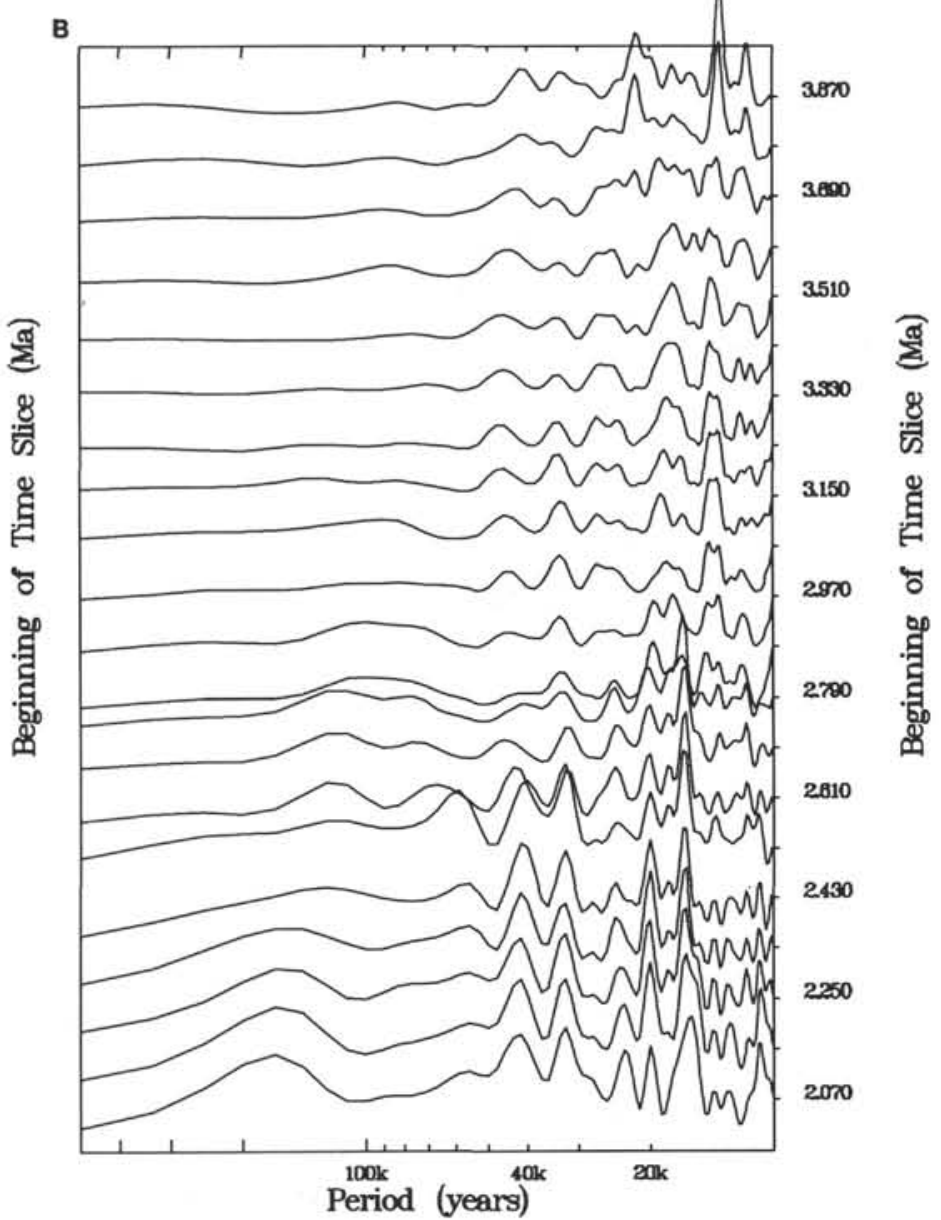

Figure 16. A. Evolutionary spectra for Site 806 grain-size data from 5 to $2 \mathrm{Ma}$. Window and offset same as in Figure 2. B. Evolutionary spectra for Site $806 \delta^{18} \mathrm{O}$ data from 5 to $2 \mathrm{Ma}$. Window and offset same as in Figure 2. 

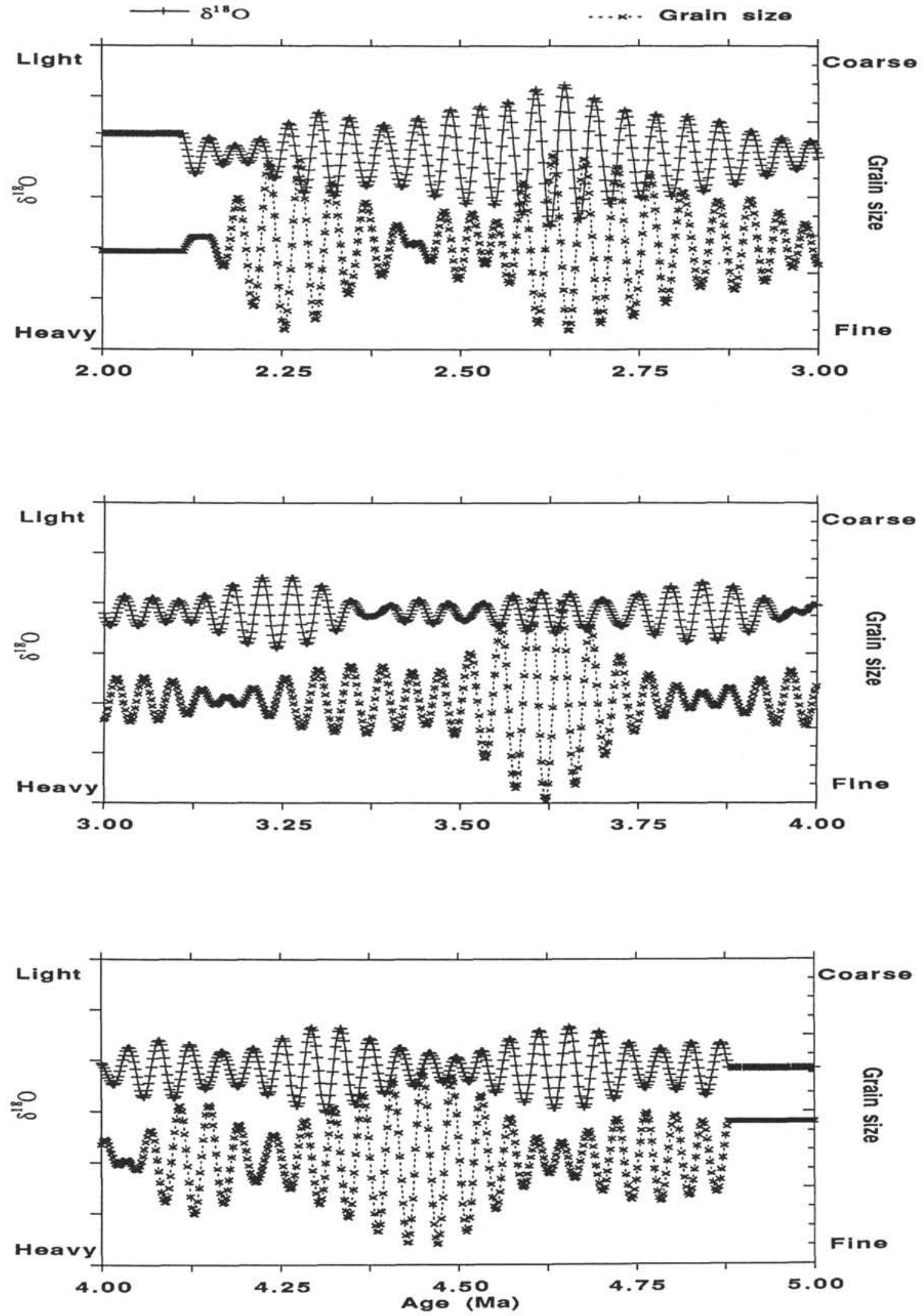

Figure 17. Comparison of grain-size (dash) and $\delta^{18} \mathrm{O}$ (solid) records, both filtered with bandpass filter centered on $41,000 \mathrm{yr}$. Time interval is 5-2 Ma. Filter goes to zero at 32,000 and $60,000 \mathrm{yr}$. 

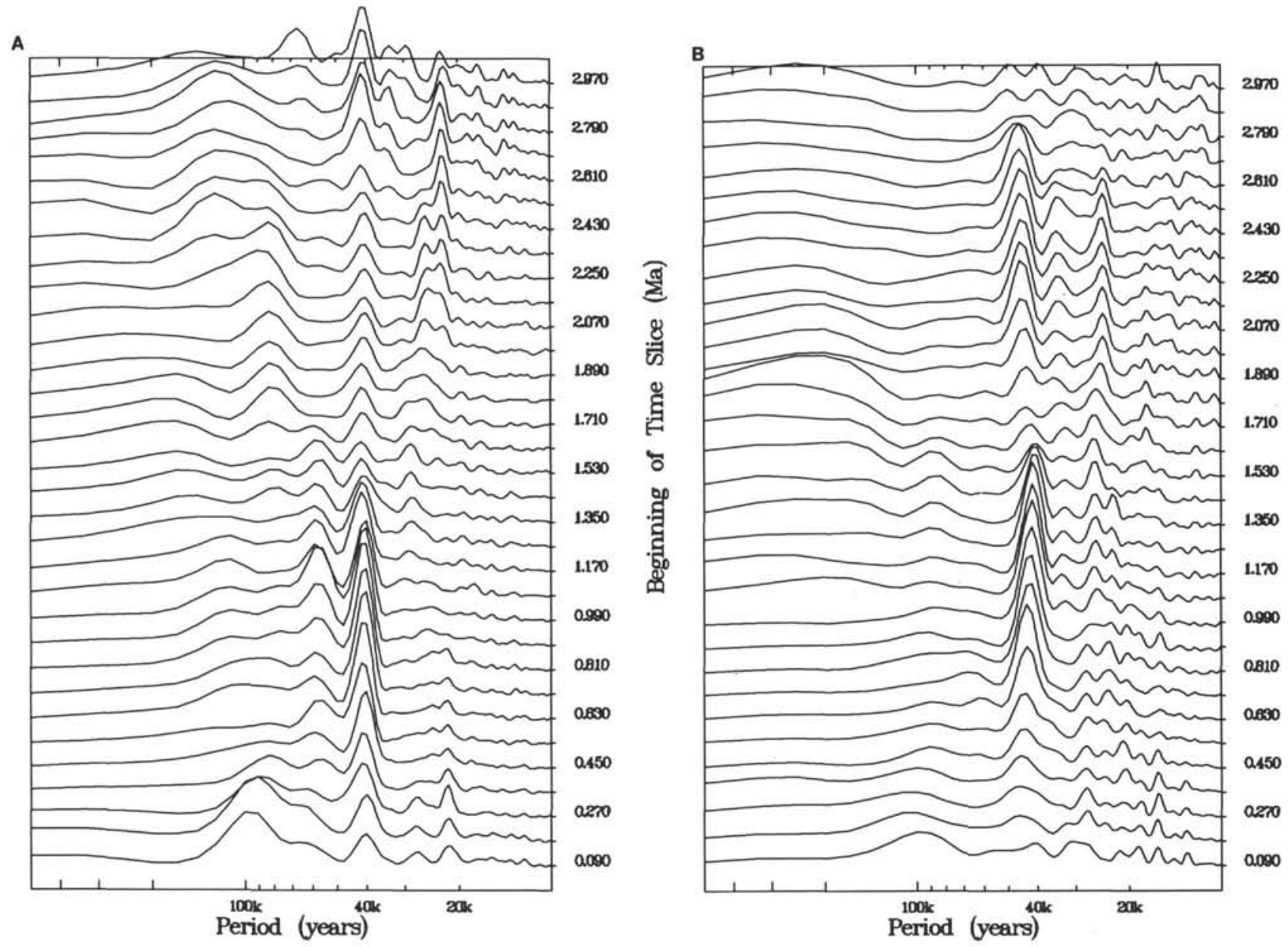

Figure 18. A. Evolutionary spectra from DSDP Site 573 GRAPE-derived carbonate record in the central equatorial Pacific, 4500-m water depth, 5-2 Ma. Windows and offset as in Figure 2. B. Evolutionary spectra from Site 806 GRAPE record, 5-2 Ma. Windows and offset as in Figure 2. 